ارزيابى كارايى سامانههاى ماشين بردار يشتيبان و شبكه عصبى مصنوعى

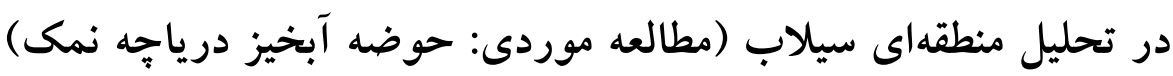

\author{
ابر اهيم شريفى گرمدره'، مهدى وفاخواه'” و سيد سعيد اسلاميانج \\ (تاريخ دريافت: ب/r/T
}

جكيده

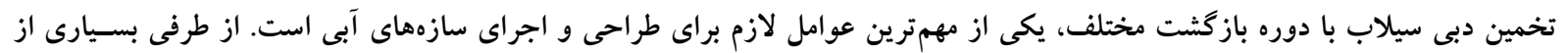

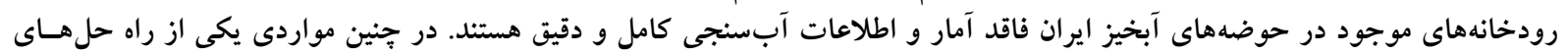

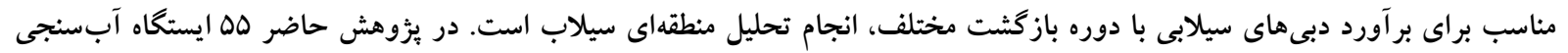

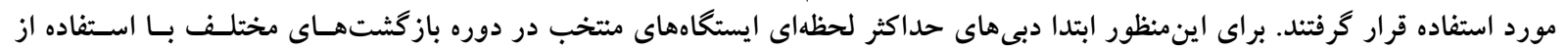

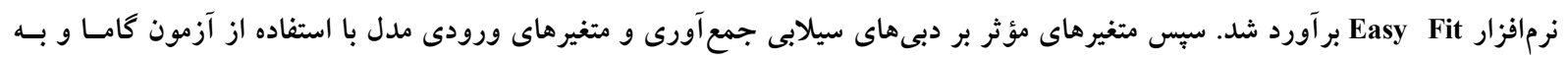

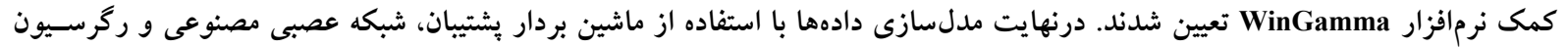

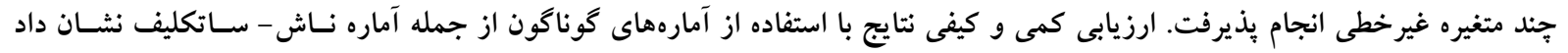

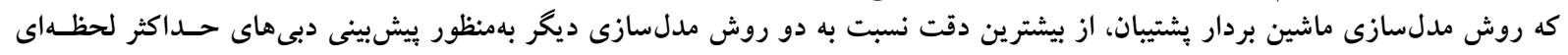

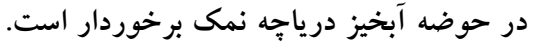

وازههاى كليدى: ايستحاه آبسنجى، دوره بازگشت، آزمون گاما، ماشين بردار بشتيبان، حوضه آبخيز درياجه نمى

ا. كروه مهندسى آبخيزدارى، دانشكده منابع طبيعى، دانشگاه تربيت مدرس

r. كروه مهندسى آب، دانشكده مهندسى كثاورزى، دانشخاه صنعتى اصفهان، اصفهان

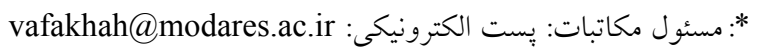


داد كه شبكههاى عصبى مصنوعى نسـبت بـه روش مـدلسبـازى ركرسيون جنادمتغيره داراى دقت بـالاترى هسـتند. شـوو و اواردا

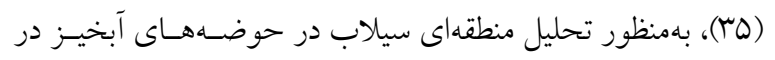

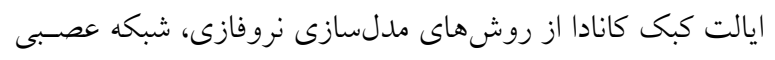

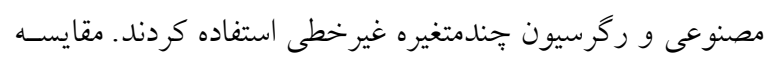

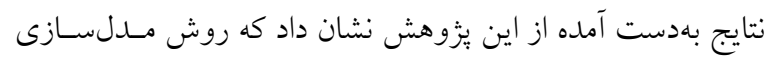

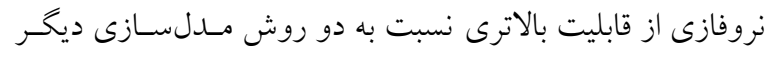

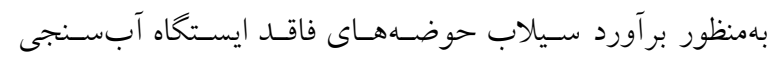

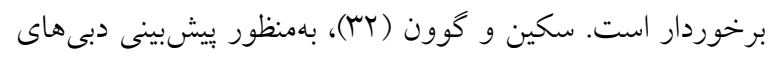

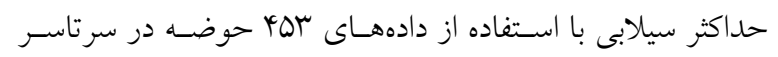

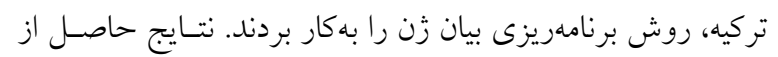

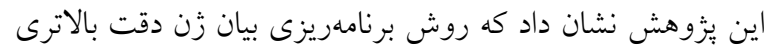

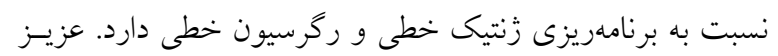

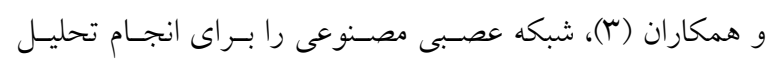

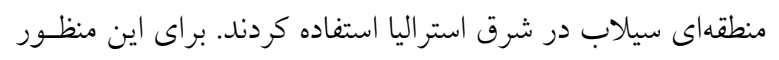

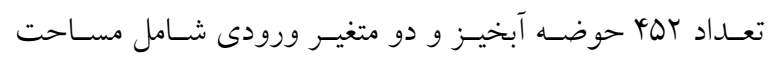

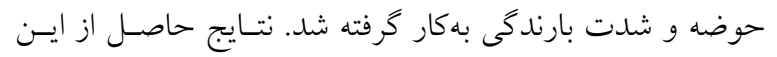

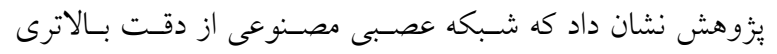

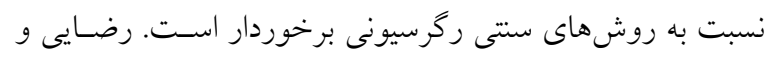

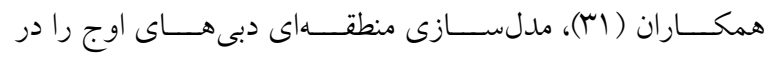

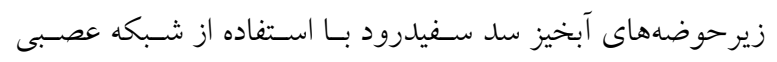
مصنوعى انجام دادند. مقايسه نتـايج دبسى هــاى اوج مشـاهدهاى و و

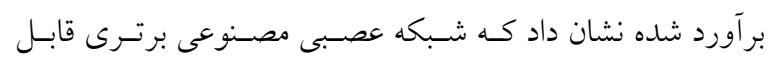

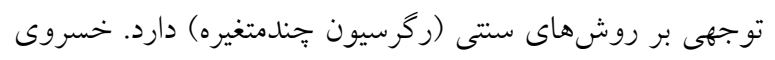

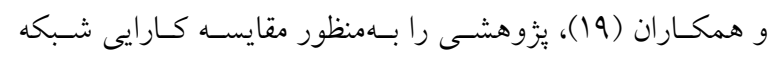

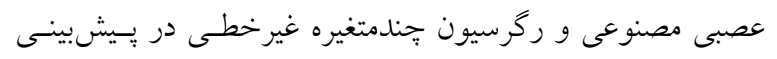

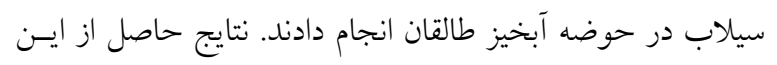

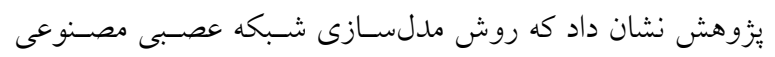

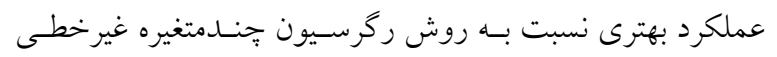

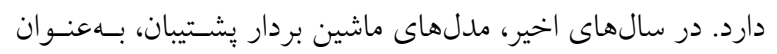

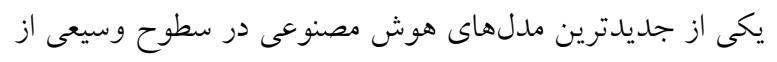

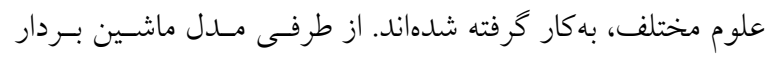

مقدمه سيلاب، بديدهاى است كـه در آن جريـان رودخانسه و سططح آب

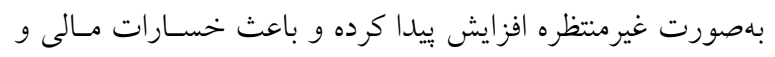

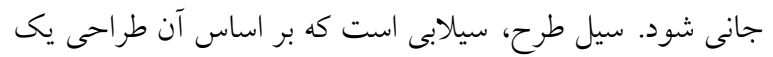

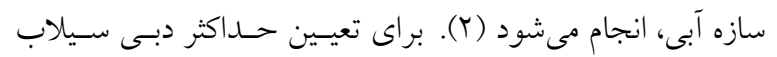

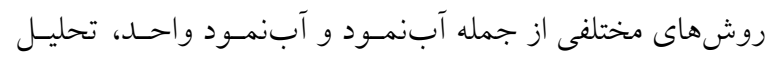

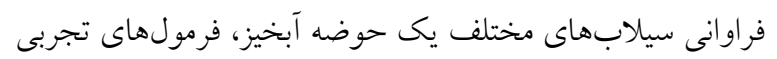

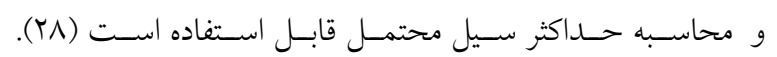

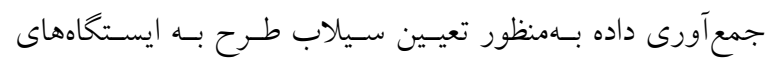

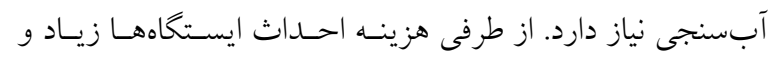

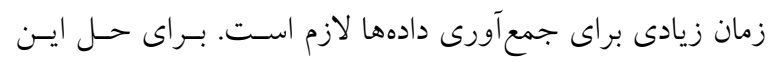

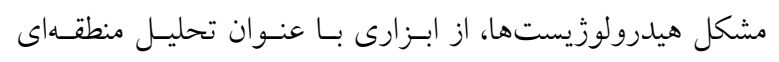

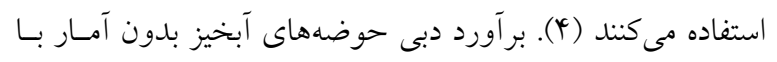

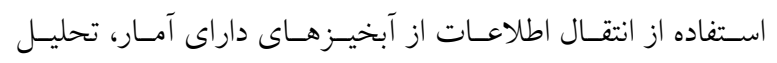

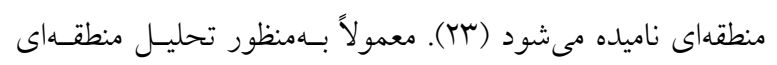

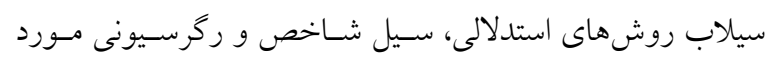

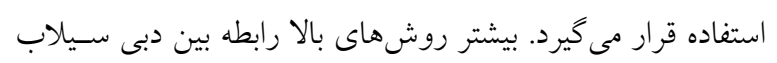

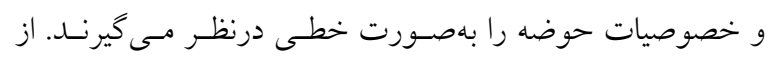

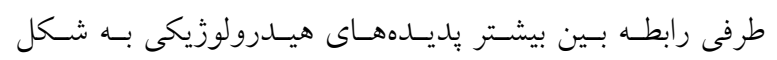

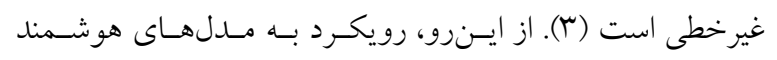

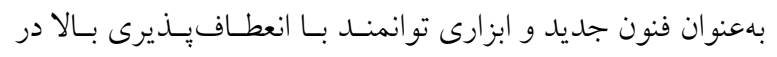

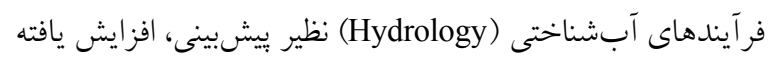

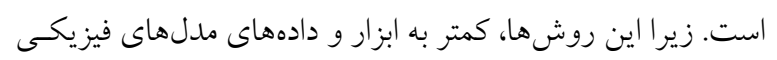

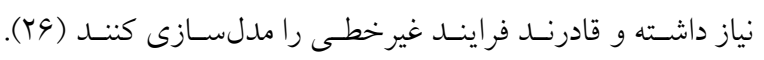

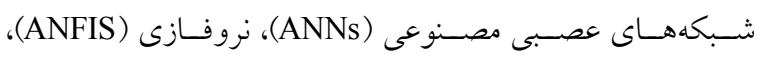

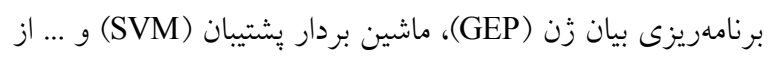

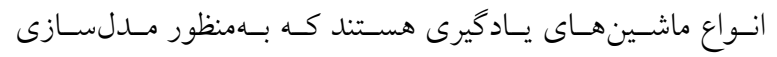

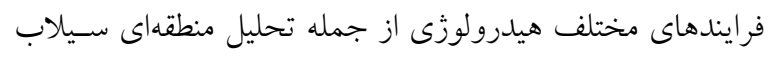

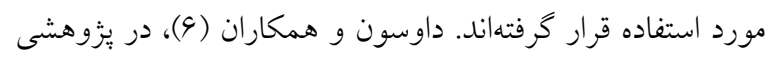

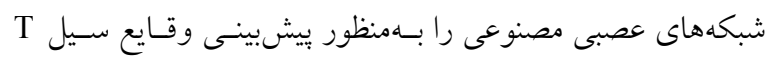

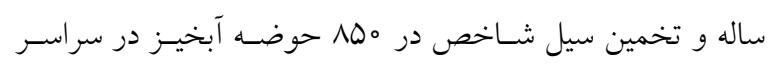

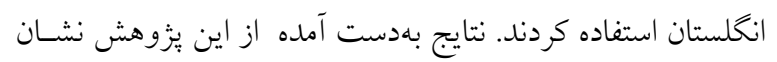




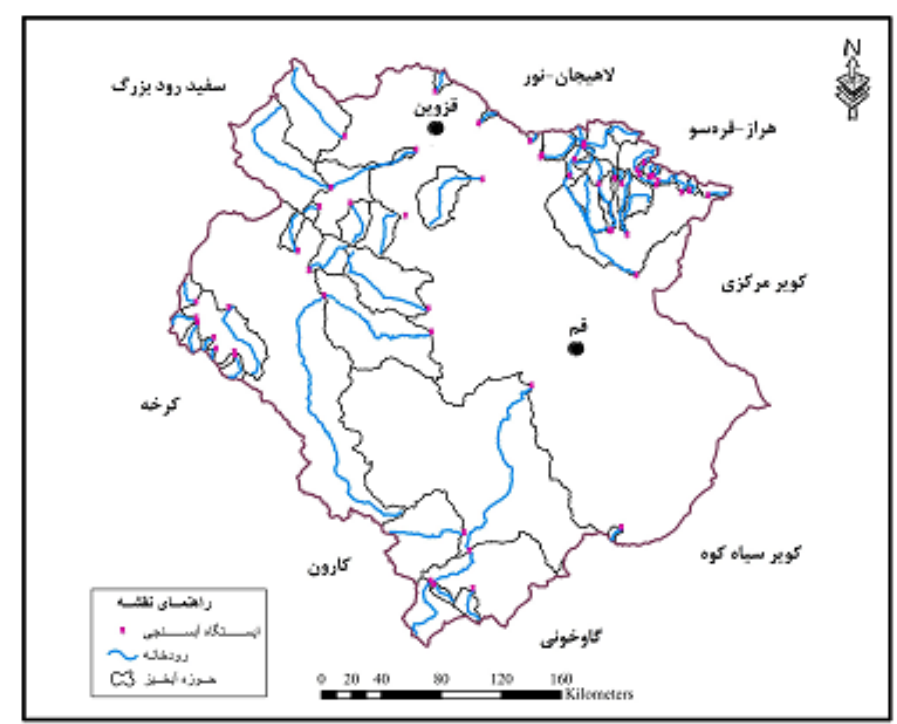

شكل ا. موقعيت ايستكاههاى مورد مطالعه در حوضه آبخيز درياجه نمك

خروجى هدف استفاده كرد، آزمون كاما است (YY). بنابر اين هدف از يزوهش حاضر، مقايسه عملكرد ماشين بردار يشتيبان بـا شـبكه هاى عصبى مصنوعى و رگرسيون جندمتغيره غير خطى بـهمنظور مدلسازى دبى هاى حداكثر لحظـهاى در حوضـه آبخيـز درياجـهـ نمك بر اساس توانايى آزمون كاما در انتخـاب متغيرهـاى ورودى مدلها است.

\section{مواد و روشها}

منطقه مورد مطالعه

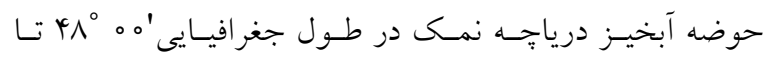

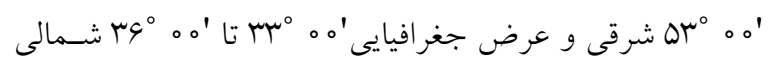
با مساحت •9rDD كيلومتر مربع واقـع شـده اسـت. شـكل (1)

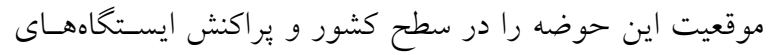

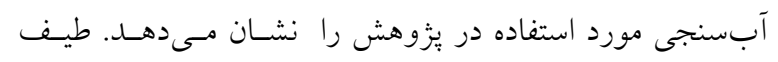

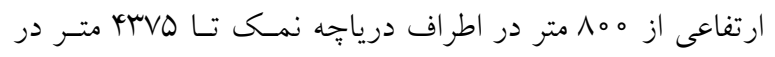

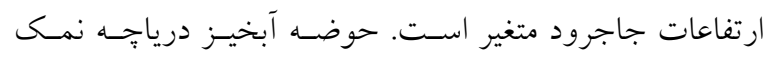
شامل جند حوضه آبخيز اصلى كو جکىتر شور، كرج، جـاجرود، قرهجاى، كوير ميقان و قمرود است. آبخيز رودخانههـاى شـور، كرج و جاجرود در شمال حوضه آبخيز و در دامنههاى جنسوبى
يشتيبان براى تحقيقات مرتبط با تحليـل منطقـهاى سـيلاب، زيـاد استفاده نشده است. زكريا و شبرى (أl)، روش مدلسازى ماشين بردار يشتيبان را بـهمنظور بــيشبينسى دبسىهـاى حســاكثر در دوره باز كشتهاى ه ا و ه ما سـاله بـا استفاده آمـار M M ايستخاه آب سنجى در مالزى به كار گرفتند و نتـايج آن را بـا روش ركرسـيون جندمتغيره مقايسه كردند. نتايج بهدست آمده از اين يزوهش نشان داد كه ماشين بردار يشتيبان عملكرد بهترى نسـبت بـه رگرسـيون

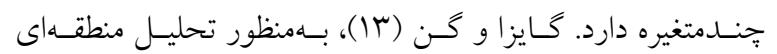
سيلاب در كانادا دو روش مدلسازى مبتنى بـر هـوش مصسنوعى شامل ركرسيون بردار يشتيبان و شبكههاى عصبى مصنوعى را بـهـ كار كرفتند. نتايج حاصله از اين يزوهش نشان داد كه ماشين بردار يشتيبان، عملكرد بهترى نسبت به روش شـبكه عصسبى مصسنوعى دارد. درنهايت، بررسى منابع مختلف نشان مىدهد كـه بزّوهشىى

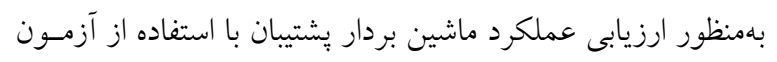

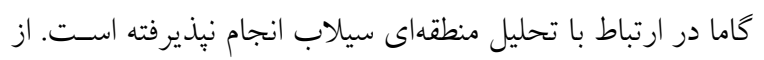
مهممترين مراحل مـدلسـازى، انتخـاب بار امترهـاى ورودى بهينـه. بهمنظور افزايش دقت و كارايى مــل و كـاهش هزينسهــا و زمـان مصرفى در مدلسازى است. از جمله روشهايى كه مىتوان بـراى

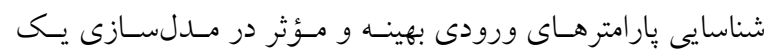




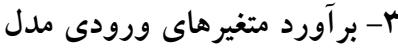

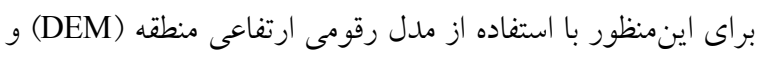

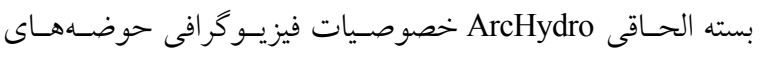

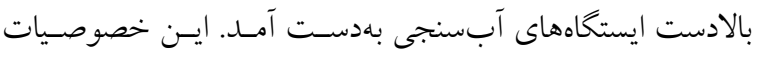

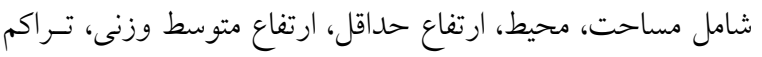

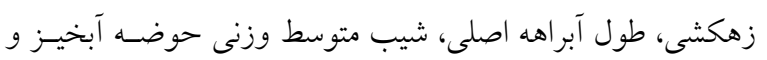

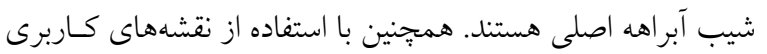

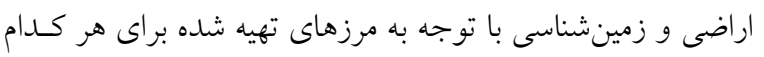

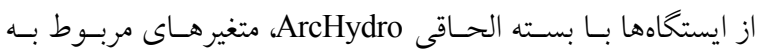

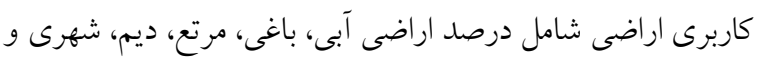

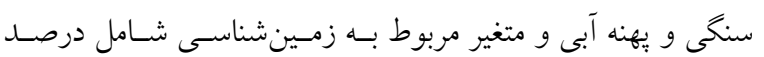
سازندهاى نفوذيذير تعيين شدند. متغيرهاى اقليمى حوضهها شامل حداكثر بارندگى Yץ ساعته، متوسط بارندكى سالانه، متوسط تبخير

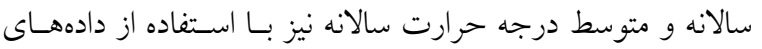

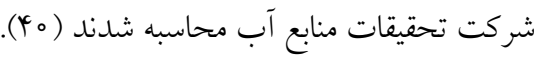

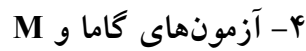

آزمون كاما (Gamma test) يكى ابزار مدلسازى غير خطى است كه

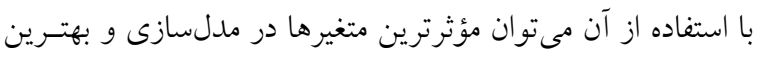

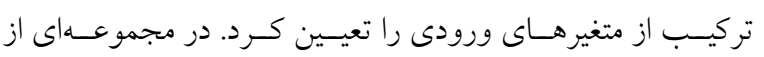
دادههاى ورودى و خروجى كه از متغيرهاى واقعى ساخته شدهاند.

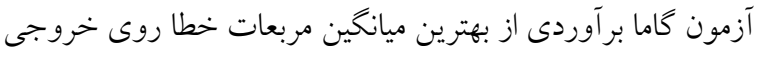

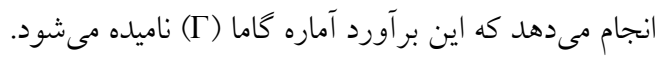
در يكى فرض مجموعه زير را در نظر بكيريد: $\left\{\left(\mathrm{x}_{\mathrm{i}}, \mathrm{y}_{\mathrm{i}}\right), 1 \leq \mathrm{i} \leq \mathrm{m}\right\}$

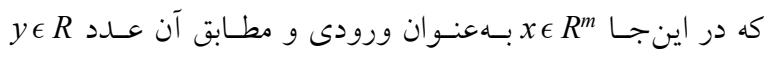
بلعنوان خروجى در نظر مى گيريم و فرض مى كنيم كه بردارهـاى

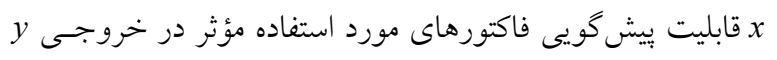

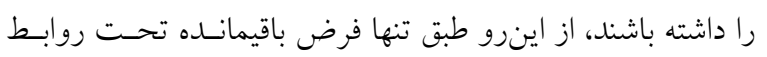
سيستم كنترل رابطه زير را دنبال مى كنيم: $y=f\left(x_{1}, \ldots, x_{M}\right)+r$ كه در اينجا f يك تابع نرم است و r يك متغير تصادفى است كسه
كوههاى البرز مركزى و آبخيز قره:اى، كوير ميغان و قمرود در

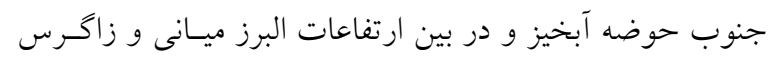

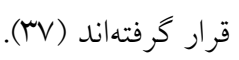
مراحل انجام تحقيق به شرح ذيل است: 1- انتخاب ايستخاههاى آبسنجى

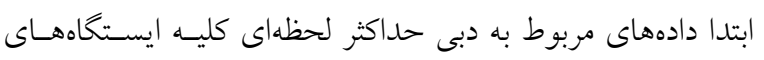

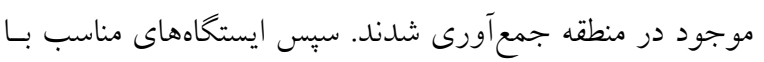

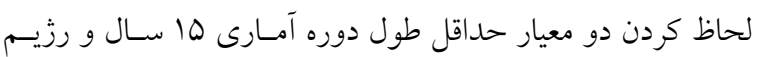

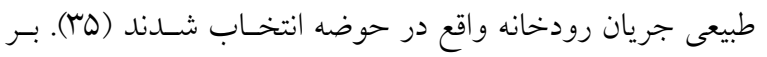

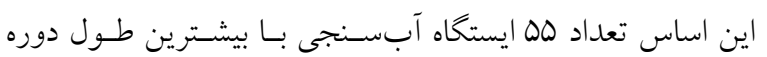

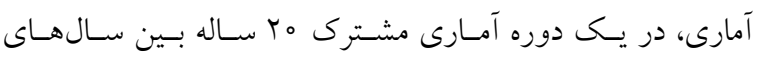

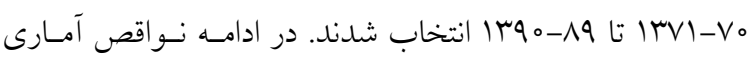

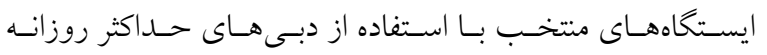

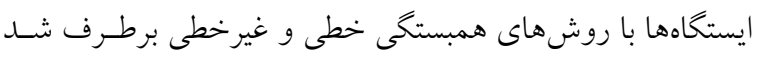

\section{Y- تجزيه و تحليل فراوانى سيلاب}

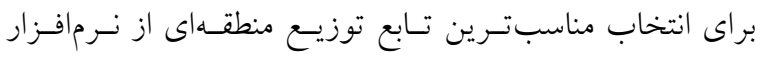

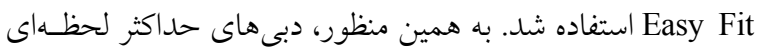

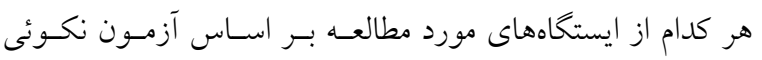
برازش كلمو گروف- اسـميرنوف (Kolmogorov Smirnov test)،

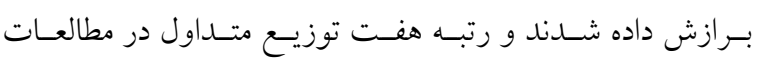

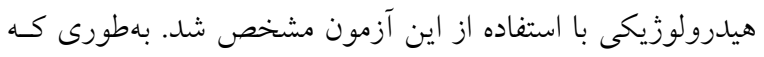

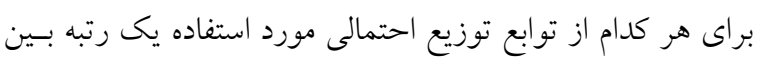

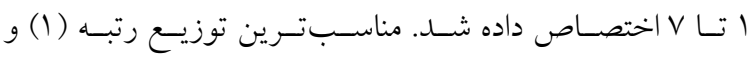

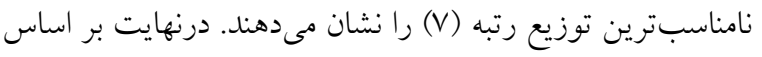

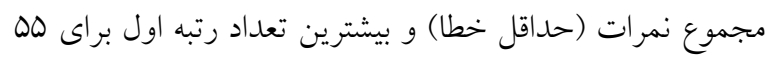

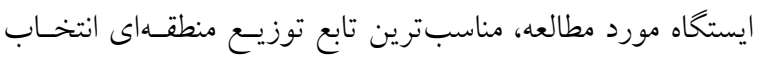

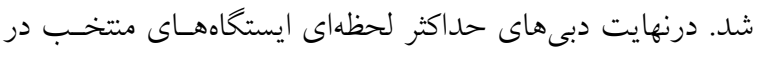

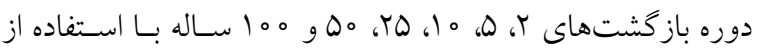
توزيع مناسب تعيين شدند (1). 
زَزمونهاى كاما و M از قابليتهاى نرمافزار WinGamma است.

ه- رگرسيون جندمتغيره غيرخطى (MNLR) بهمنظور برآورد دبىهاى حداكثر لحظهاى با استفاده از ركرسيون جند متغيره غيرخطى، يك معادله بين دبىهاى حسـاكثر لحظـهاى با دوره باز گشت هاى مختلف (متغيرهاى وابستهـ) و خصوصسيات فيزيو گرافى، اقليمى، كاربرى اراضسى و زمسينشناسـى (متغيرهـاى

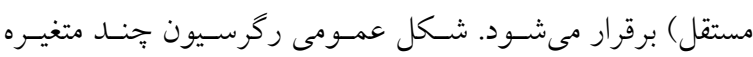
غيرخطى باهورت رابطه (1) است $\mathrm{Q}_{\mathrm{T}}=\mathrm{mA}^{\mathrm{a}} \mathrm{B}^{\mathrm{b}} \mathrm{C}^{\mathrm{c}} \ldots \mathrm{Z}^{\mathrm{Z}}$

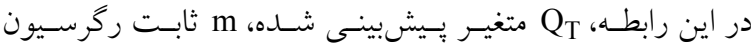

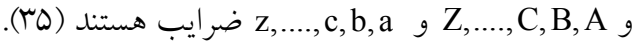

9- ماشين بردار بشتيبان (SVM) ساختار مدل ماشين بردار يُشتيبان توسط وينكى (Vapnik) معرفى

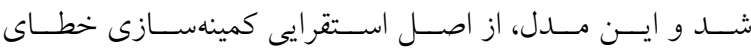
سـاختارى بهـره مى جويســ. مــلهــاى ماشـين بــردار بشــيبان

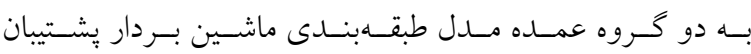
و مدل رگرسيون ماشين بردار (Support Vector Classification) يشتيبان (Support Vector Regression) تقسيمبندى مى شـوند. از مدلهـاى طبقهبنـدى ماشـين بــردار يشـتيبان بـراى حــل مســائل طبقهبندى دادههايى كه در كلاسهـاى مختلـف قـرار مسى گيرنــد

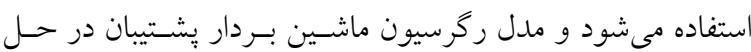

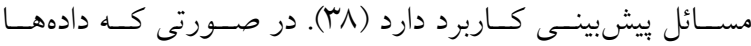
بهصورت خطى قابل تفكيك باشند معادله بهصورت زير است: $\mathrm{y}=\mathrm{f}(\mathrm{x})=\operatorname{sign}\left[\sum_{\mathrm{i}=1}^{\mathrm{n}} \mathrm{y}_{\mathrm{i}} \mathrm{a}_{\mathrm{i}}\left\langle\mathrm{x}_{\mathrm{i}}, \mathrm{x}_{\mathrm{j}}\right\rangle+\mathrm{b}\right]$

اخر دادهها بهصورت خطى قابل تفكيك نباشند مى توان بـا اعمـال بيش يردازش، نمونهها را با يكى تبديل غيرخطى به يك فضـاى بـا بعد زياد انتقال داد و در آن فضا حاصل ضرب داخلى انجـام داد و ثابت كرد كه اخر يك هسته متقارن شرايط قضيه مرسر (Mercer) را داشته باشد، اعمال اين هسـته در فضـاى ورودى بــا بعـد كـمـ
نشاندهنده مقادير نويز است. بـهـــوركلى و بــون كـاهش تـابع مىتوان توضيح داد كه r برابر صفر واريانس نويز كــاندار اسـت. آماره كاما م از قسمتى از واريانس خروجى كه نمسىتوانــ بــراى يك مــدل نـرم محاسـبه شـود، بـهدسـت مسى آيـد. فـرض كنيــ امين نزديكترين همسايه در يـك فاصسله اقليدسى ، x x $\{i, k\}$

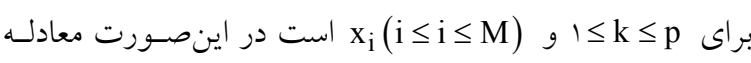
اصلى نيازمند برآورد م است.

$\gamma_{\mathrm{M}}(\mathrm{k})=\frac{1}{r \mathrm{M}} \sum_{\mathrm{i}=1}^{\mathrm{M}}\left|\mathrm{y}_{\mathrm{N}}[\mathrm{i}, \mathrm{k}]-\mathrm{y}_{\mathrm{i}}\right|^{r}, \quad(1 \leq \mathrm{k} \leq \mathrm{p})$

$\delta_{\mathrm{M}}(\mathrm{k})=\frac{1}{\mathrm{M}} \sum_{\mathrm{i}=1}^{\mathrm{M}}\left|\mathrm{x}_{\mathrm{N}[\mathrm{i}, \mathrm{k}]}-\mathrm{x}_{\mathrm{i}}\right|^{\mathrm{r}}, \quad(\mathrm{l} \leq \mathrm{k} \leq \mathrm{p})$

كه در اينجا |.| فاصله اقليدسى را مشـخص مسىكنـد و بـهمنظور محاسبه م كافى است كه يك خـط رگرسـيونى حسـاقل مربعـات براى $\gamma_{M}(\mathrm{k})$ و ايجاد شود.

$\gamma=\mathrm{A} \delta+\Gamma$

مقدار آماره Г عرض از مبدأ خط رخرسيون است. A، شيب خـط ركرسيون است كه نشاندهنده يبيجيد گیى مللى اسـت كـه از روى

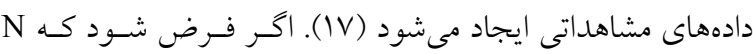
متغير ورودى بـر وقــوع يديـدهاى مسؤثر باشـد، در ايسن صـورت

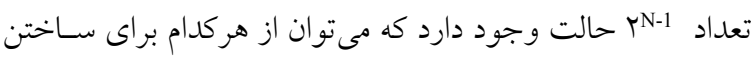
مدل استفاده كرد. استفاده از همه تركيبها، بـراى يـافتن بهتـرين تركيب ورودى به مدل بسيار وقت گير است. بنابراين در شـرايطى كه تعداد متغيرهاى ورودى از مدل زياد باشد، مىتــوان از آزمـون كاما بهمنظور انتخاب تركيب بهينه اسـتفاده كـرد. بــمنظور تعيسين تركيب بهينه از متغيرها ابتدا با اسـتفاده از تمـام ورودىهـا ميـزان آماره گاما (Г) محاسبه مى شود. سبس با حـذف يكسى از متغيرهـا ميزان آماره كاما (Г) تعيين مىشود. در ادامه متغير حذف شده بـهـ مجموعه بركردانده و متغير ديخرى حذف مىشود و مقـدار آمـاره كاما (Г) محاسبه مىشود. اين فرايند براى تمام متغيرهاى ورودى مدل انجام مىشود بهطورى كه مهمترين متغيرهـا بيشـترين ميـزان

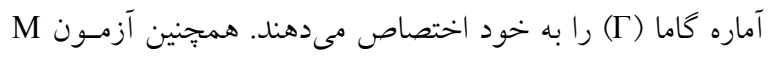
بهمنظور تعيين دادههاى آموزش و آزمون بـراى رسـيدن (M-test)

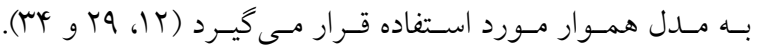


جدول ا. معادلات توابع مختلف كرنل

\begin{tabular}{|c|c|c|}
\hline هارامتر & معادلات & تابع كرنل \\
\hline- & $K\left(x_{i}, x_{j}\right)=x_{i} \cdot x_{j}$ & هسته خطى \\
\hline$\gamma, d$ & $K\left(x_{i}, x_{j}\right)=\left(\gamma x_{i} \cdot x_{j}+r\right)^{d}$ & هسته يلىنوميال \\
\hline$\gamma$ & $\mathrm{K}\left(\mathrm{x}_{\mathrm{i}}, \mathrm{x}_{\mathrm{j}}\right)=\exp \left(-\gamma\left\|\mathrm{x}_{\mathrm{i}}-\mathrm{x}_{\mathrm{j}}\right\|^{\top}\right.$ & هسته تابع پيايه شعاعى \\
\hline
\end{tabular}

يّارامترهاى مجهول، مناسب ارزيابى شـده اسـت (TI) ايـن نـوع

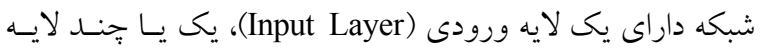
مخفى (Hidden Layer) و يكى لايسه خروجسى (Output Layer)

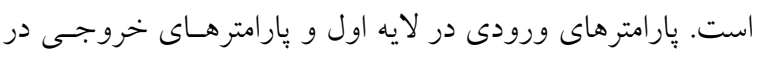

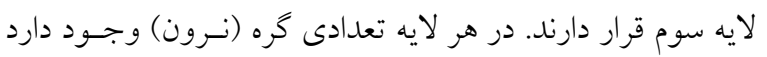

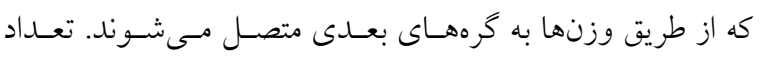

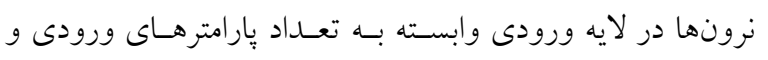

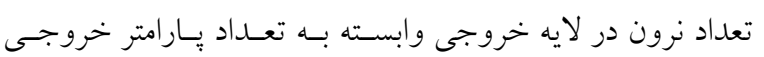

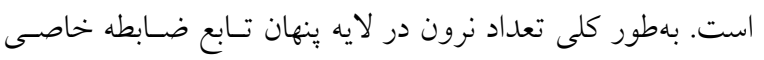
نبوده و تعيين تعداد مناسب آن فقط از طريق سعى و خطا امكـان

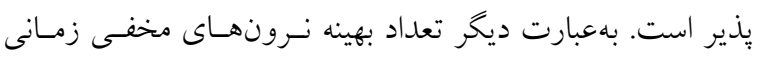

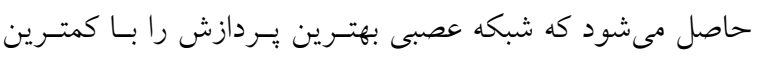

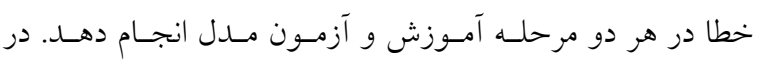

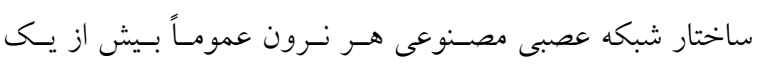

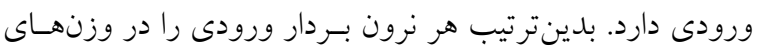

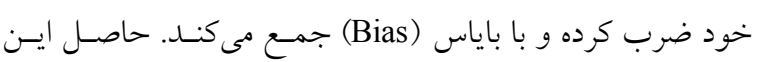

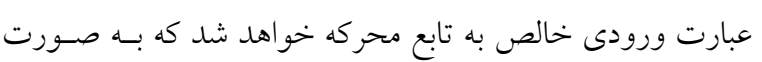
زير بيان مىشود: - - ن

net $_{j}=\sum_{i=1}^{n} w_{i j} x_{j}+b_{i}$

كــه در آن، ماتريس وزنهاى شبكه، X

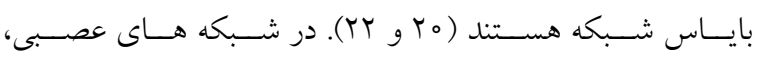

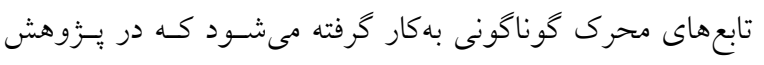

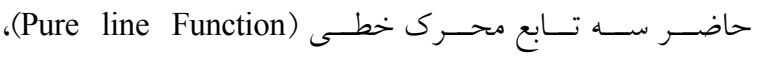

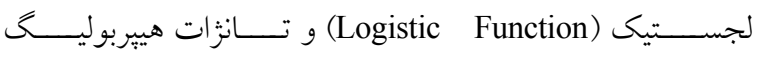

مىتواند بهعنوان حاصل ضرب داخلى با بعـــ زيـاد تلقـى شـود و

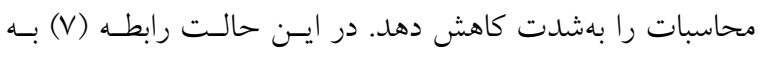
رابطه (^) تغيير مى يابد: $\mathrm{y}=\mathrm{f}(\mathrm{x})=\operatorname{sign}\left[\sum_{\mathrm{i}=1}^{\mathrm{n}} \mathrm{y}_{\mathrm{i}} \mathrm{a}_{\mathrm{i}} \mathrm{K}\left(\mathrm{x}_{\mathrm{i}}, \mathrm{x}_{\mathrm{j}}\right)+\mathrm{b}\right]$

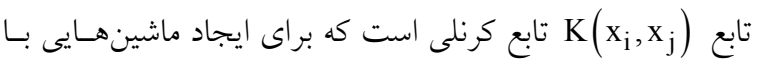
انواع مختلف از سطوح تصميمخيرى غيرخطى در فضاى دادههـا،

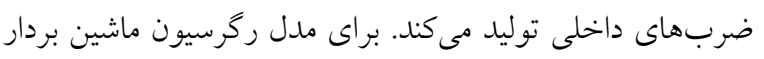

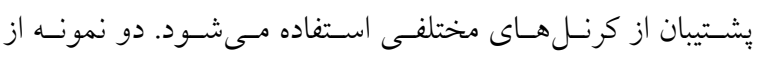

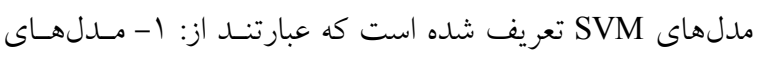

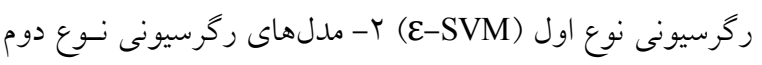
(V-SVM)

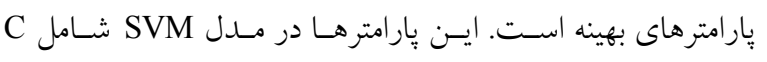

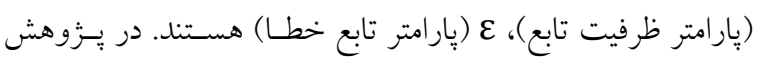

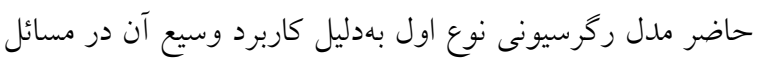

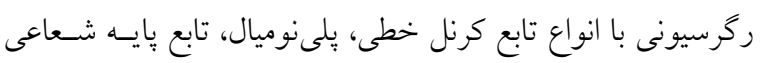

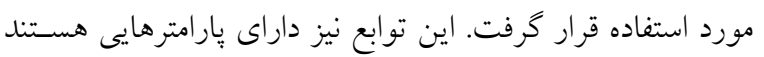

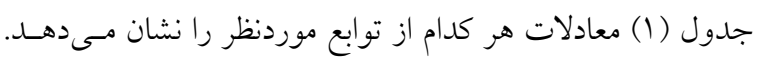

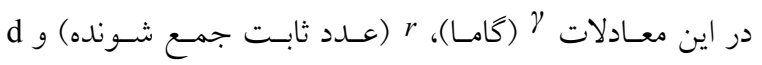

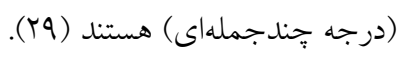

\section{(ANNs) شبكه هاى عصبى مصنوعى -V}

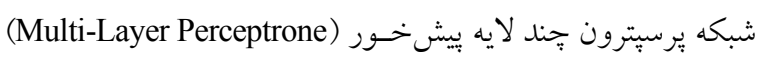

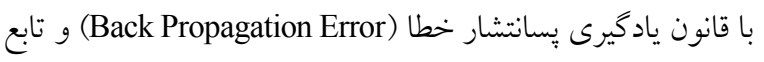

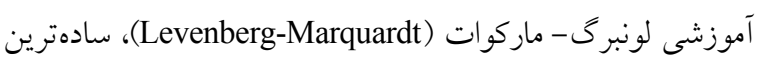
و ير كاربردترين نوع شبكه عصبى است كه در خصوص تخمسير مونسين 


\begin{tabular}{|c|c|c|c|c|c|c|c|}
\hline \multicolumn{8}{|c|}{ جدول r. انتخاب بهترين تابع توزيع آمارى منطقهاى } \\
\hline 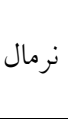 & كمبل & كَاماى دو & سيرسون نوع & لو يَّ نرمال دو امترى & لو يار نرمال سه & لوى بيرسون & توزيع آمارى \\
\hline$\mu \circ \Lambda$ & $r \Delta \wedge$ & rlo & Trt & THG & 191 & 1149 & جمع نمرات (حداقل خطا) \\
\hline$r$ & $r$ & 0 & 9 & 4 & ir & IV & تعداد رتبه اول \\
\hline
\end{tabular}

كه در آن qu(t) دبى مشاهده شده، qu تعداد دادههاى مشاهداتى، ميانخين دبى بيش $\overline{q_{p}(t)}$

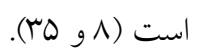

\section{نتايج و بحث} بس از مشخص شدن ايستخاههاى مـورد نظـر بـهمنظور محاسـبه دبىهاى حداكثر لحظهاى در دوره باز خشتهاى مختلف، بهتسرين تابع توزيع منطقهاى انتخاب مىشود. بر همين اساس توزيع لـوى بيرسون نوع سوم (LP) با كمترين ميزان خطا و بيشسترين تعـداد رتبه اول بهعنوان مناسبترين تابع براى برازش دبىهاى حسـداكثر

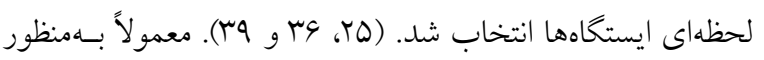

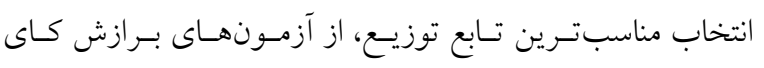

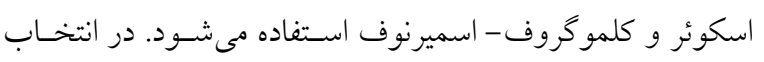
توزيع مناسب هيج گونـهـ تـو افقى بـين هيدرولوزيسـتهــا وجــود ندارد. وليكن مىتوان توزيع مناسـب را براسـاس كمتــين ميـزان

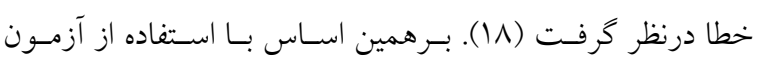
برازش كلموكروف - اسميرنوف مناسبترين تـابع توزيـع آمـارى انتخاب شد. جدول (Y) نتايج انتخاب بهترين تابع توزيع منطقهاى

$$
\text { نشان مي دهد. }
$$

جدول (r)، نتايج مربوط بـه آزمسون كامـا بـهمنظور انتخـاب

تركيب بهينه را نشان مسىدهــ. بـهـنظور تعيسين تركيـب بهينـه از

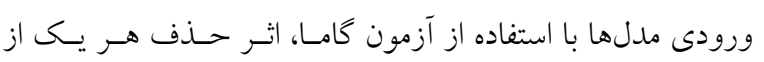

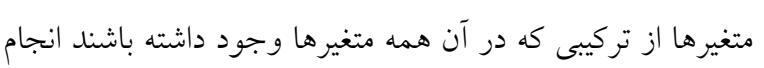
يذيرفت و در هر مرحله مقدار آماره كاما محاسبه و با مقدار آماره كاما بدون حذف متغير مقايسه شد. تركيبـاتى كـه در آنهـا مقـدار
براى لايههاى مخفـى و تـابع (Hyperbolic Tangent Function) محرى خطى براى لايه خروجى مورد استفاده قرار خرفت.

1- نرمالسازى دادهها

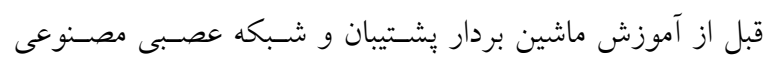

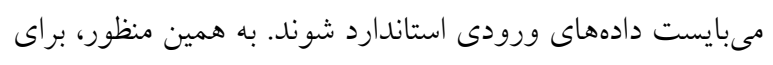
استاندارد كردن دادهها از رابطه ( ا () استفاده مى شود: $\mathrm{X}_{\text {Normal }}=\circ / \wedge \times \frac{\left(\mathrm{X}_{\mathrm{i}}-\mathrm{X}_{\min }\right)}{\left(\mathrm{X}_{\max }-\mathrm{X}_{\min }\right)}+\circ / 1$

كه در آن، Xormal

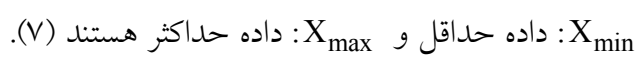

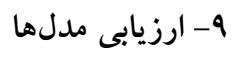

بهمنظور ارزيابى نتايج مدلها از نمايههاى آمـارى ضـريب تبيـين

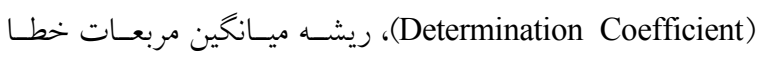
و وريب كارايى ناش - سـاتكليف (Root Mean Square Error)

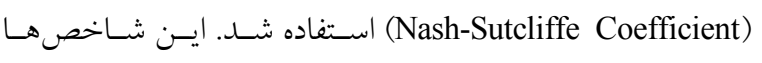
بهصورت زير محاسبه مىشوند:

$$
\begin{aligned}
& \mathrm{R}^{r}=\frac{\sum_{i=1}^{n}\left(\mathrm{q}_{\mathrm{p}(\mathrm{t})}-\overline{\mathrm{q}_{\mathrm{o}(\mathrm{t})}}\right)\left(\mathrm{q}_{\mathrm{p}(\mathrm{t})}-\overline{\mathrm{q}_{\mathrm{p}(\mathrm{t})}}\right)}{\sum_{\mathrm{i}=1}^{\mathrm{n}}\left(\left(\mathrm{q}_{\mathrm{p}(\mathrm{t})}-\overline{\mathrm{q}_{\mathrm{o}(\mathrm{t})}}\right)^{r}\right)^{\circ / \Delta}\left(\left(\mathrm{q}_{\mathrm{o}(\mathrm{t})}-\overline{\mathrm{q}_{\mathrm{p}(\mathrm{t})}}\right)^{r}\right)^{\circ / \Delta}} \\
& \mathrm{RMSE}=\sqrt{\frac{1}{\mathrm{n}} \sum_{i=1}^{n}\left(\mathrm{q}_{\mathrm{p}(\mathrm{t})}-\mathrm{q}_{\mathrm{o}(\mathrm{t})}\right)^{r}} \\
& \mathrm{NSC}^{\mathrm{n}}=1-\frac{\sum_{i=1}^{\mathrm{n}}\left(\mathrm{q}_{\mathrm{o}(\mathrm{t})}-\mathrm{q}_{\mathrm{p}(\mathrm{t})}\right)}{\sum_{i=1}^{n}\left(\mathrm{q}_{\mathrm{o}(\mathrm{t})}-\overline{\mathrm{q}_{\mathrm{o}(\mathrm{t})}}\right)}
\end{aligned}
$$


نشريه علوم آب و خاك (علوم و فنون كثاورزى و منابع طبيعى) / سال بيست و سه / شماره اول / بهار 1941

جدول r. انتخاب متغيرهاى تأثير گذار بر دبىهاى سيلاب با استفاده از آزمون كاما

\begin{tabular}{|c|c|c|c|c|c|}
\hline 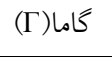 & متغير & شماره تركيب & 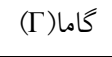 & متغير & شماره تركيب \\
\hline o/IVAY & All- شيب متوسط وزنى & ir & ONAKY & All & 1 \\
\hline$\circ / I V V r$ & ارتفاع ميانخين -All & ir & $\circ / T \circ V V$ & مساحت-All & r \\
\hline$\circ / I V V r$ & حداكثر بارندگى ب باعته-All & 14 & $\circ / r_{0}$ & تراكم زهكشى-All & r \\
\hline o/IVGV & طول آبراهه اصلى-All & 10 & $\circ / 190 \circ$ & All- ارتفاع حداكثر & $r$ \\
\hline -/IVAr & شيب آبر اهه صلى-All & 19 & - /NAFE & All- محيط & 0 \\
\hline$\circ / / V \circ 4$ & متوسط درجه حرات سالانه-All & iv & $\circ / \Lambda \mu_{0}$ & درصد سازندهاى نقوذيذير-All & 4 \\
\hline $0 / 199 \mathrm{~V}$ & درصد اراضى يهنه آبى-All & 11 & ס/NHT & درصد اراضى آبى-All & v \\
\hline.$/ 1940$ & درصد اراضى مسكونى-All & 19 & $\circ / \Lambda r_{0}$ & درصد اراضى مرتعى-All & $\wedge$ \\
\hline.$/ 1940$ & درصد اراضى ديم-All & ro & $\circ / \Lambda \circ \vee V$ & درصد اراضى باغى-All & 9 \\
\hline $0 / 1099$ & ارتفاع حداقل-All & ri & o/lvar & All-متوسط بارندگى سالانه & 10 \\
\hline- & - & - & $\circ / I V A V$ & متوسط تبخير سالانه-All & 11 \\
\hline
\end{tabular}

لحظهاى در حوضه آبخيز درياجهه نمك است (ها و اسا). زيرا بـا

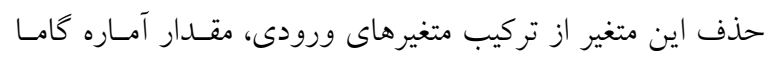

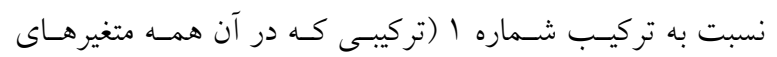

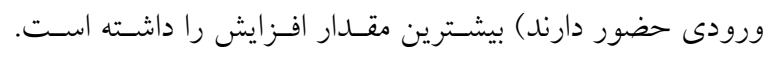

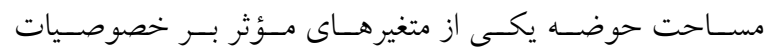

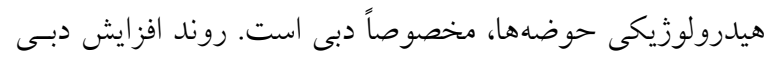

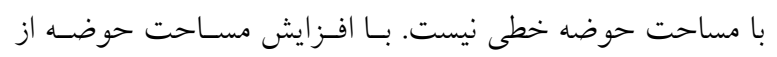

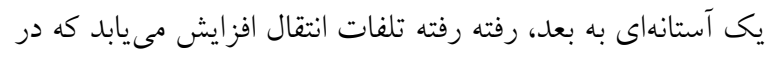

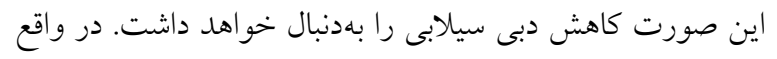

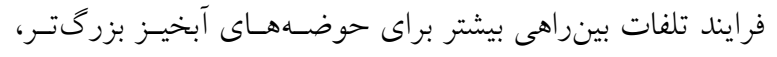

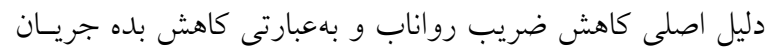

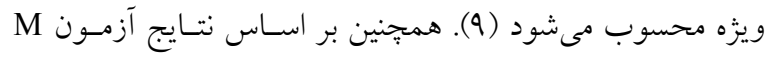

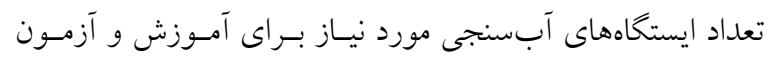

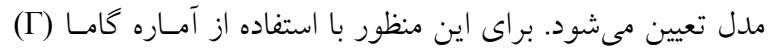

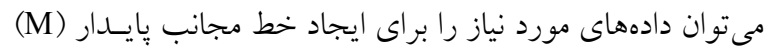

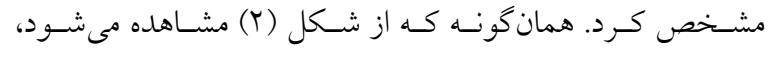

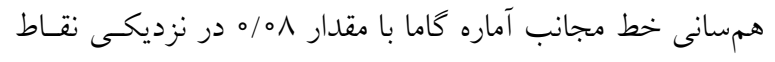

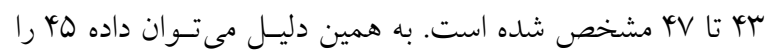

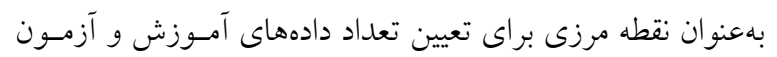

آماره كاما با حذف هر يكى از متغيرها از تركيـب همـه متغيرهـاى

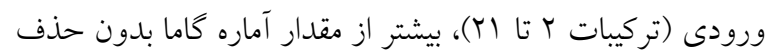

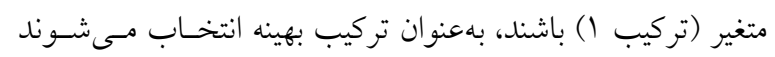

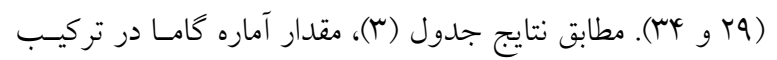

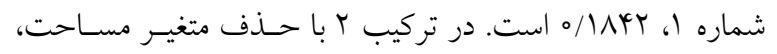

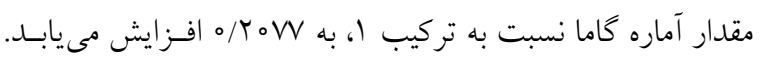

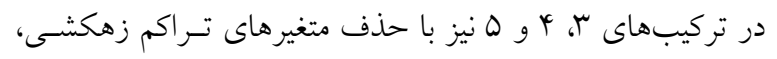

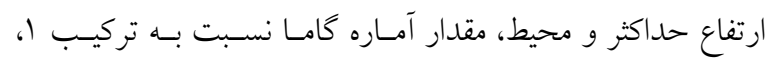

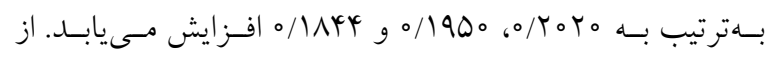

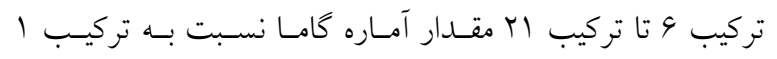
كاهش يافته است. بهعبارتى ديخر متغيرهاى غايب تركيبات كا، با،

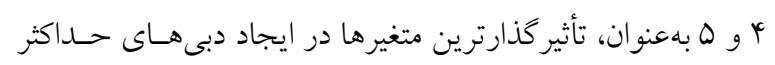

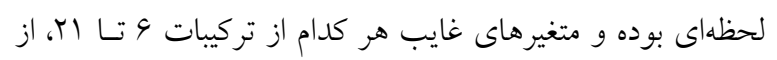

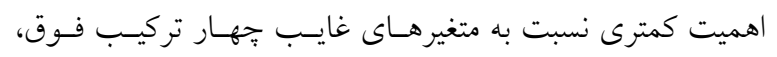
بهمنظور مدلسازى برخوردار هستند. بنابراين با توجسه بـهـ نتسيج

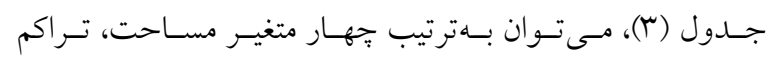

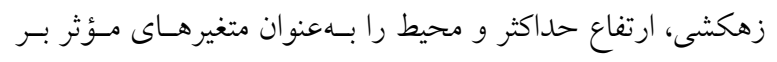

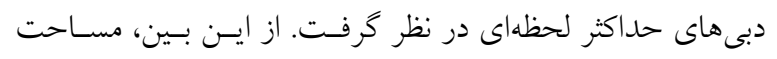

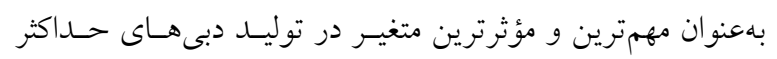




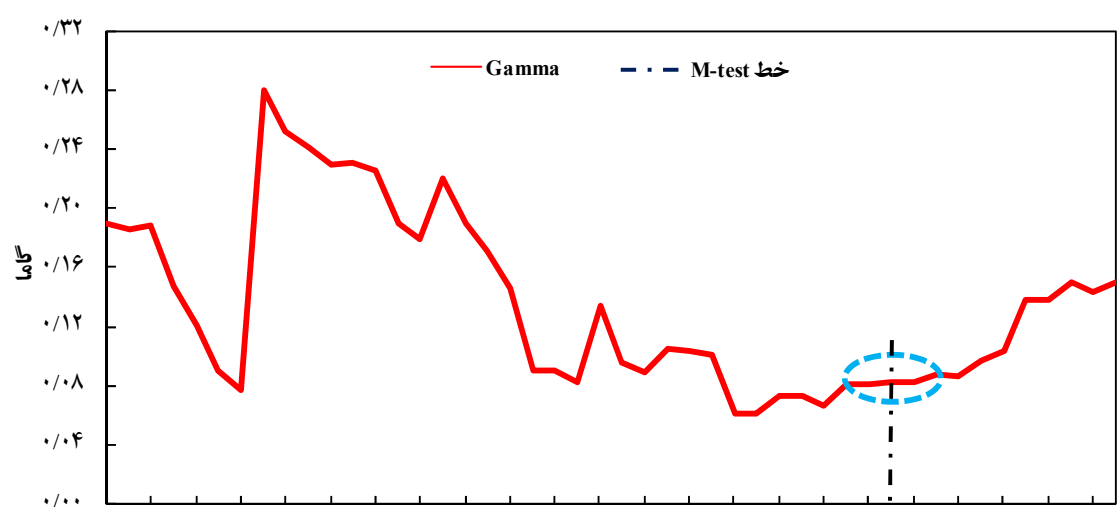

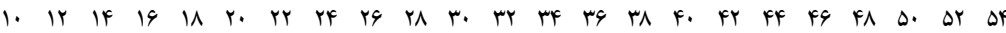
تعداد ايستكاه آبسنجى

شكل r. نمودار تغييرات مقدار آماره گاما در مقابل تعداد ايستخاههاى آبسنجى (آزمون Mدانس

جدول f. نتايج حاصل از ماشين بردار يشتيبان در مرحله آموزش و آزمون

\begin{tabular}{|c|c|c|c|c|c|c|c|c|c|c|}
\hline \multicolumn{3}{|c|}{ متغيرهاى مدل } & \multicolumn{3}{|c|}{ آزمون } & \multicolumn{3}{|c|}{ آموزش } & \multirow{2}{*}{ تابع كرنل } & \multirow{2}{*}{ دوره بازگشت } \\
\hline$\gamma$ & $\varepsilon$ & $\mathrm{C}$ & NSC & RMSE & $\mathrm{R}^{r}$ & NSC & RMSE & $\mathrm{R}^{r}$ & & \\
\hline$r / r$ & $\circ / 0 \circ$ & 90 & o/Ar & II/T & $0 / 91$ & o/N & N/Ar & ०/Ar & RBF & r \\
\hline$r$ & $\circ / 0 \circ$ & 90 & o/AF & $1 V / 9 \circ$ & $0 / 90$ & o/AY & $1 V / r q$ & O/AY & RBF & 0 \\
\hline$r / l$ & $\circ / 0 \circ$ & 9. & o/Ar & $Y Y / q V$ & $0 / 9 T$ & o/Ar & $r G / \circ V$ & ०/Ar & $\mathrm{RBF}$ & 10 \\
\hline $1 / T$ & . To & $\Delta \Delta$ & $\circ / V Q$ & rV rV & $0 / 19$ & $\circ / \mathrm{VV}$ & $0 \circ / \mu T$ & $\circ / \mathrm{VV}$ & $\mathrm{RBF}$ & ro \\
\hline $1 / T$ & $\circ / \pi \Delta$ & $\Delta \Delta$ & $\circ / V Q$ & $\varphi Q / T V$ & •/A & $\circ / V \Delta$ & $V Y / V Y$ & $\circ / \sqrt{ } 9$ & RBF & ఎ. \\
\hline $1 / T$ & $\circ / \Delta Q$ & $\Lambda^{\circ}$ & $\circ / V 1$ & $\Delta \Lambda / \Lambda Y^{\leftarrow}$ & ०/V9 & $\circ / V Y$ & $11 / \circ V$ & $\circ / V^{4}$ & $\mathrm{RBF}$ & 100 \\
\hline
\end{tabular}

شبكه درشت ناحيه مناسب يارامترها مشخص مىشود. سبس اين شبكه درشت شكسته شده و مقدار بهينه يارامترها در شـبكههـاى ريزتر تعيين مىشود. جدول (4) مقادير بهينه اين بارامترها و نتايج مربوط به مدلهاى ماشسين بـردار يشـتيبان را نشـان مىدهـد. در فرايند مدلسازى، مدلى قابل يذيرش اسـت كـه ضـريب كـارايى بالاترى در مرحله آزمون داشته باشد (rV و ه广). ارزيابى عملكرد

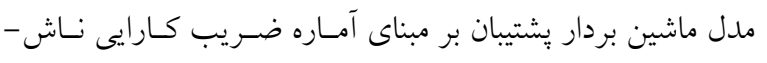
ساتكليف نشان مىدهد كه دقت مدلسازى تا دوره باز گشت يـنج سال رو به افزايش است و از آن به بعد اين دقت كاهش مىيابـد. بهطورى كه آماره ناش - ساتكليف در بهترين حالت مـدل ماشسين

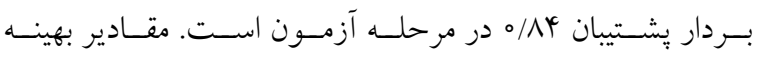

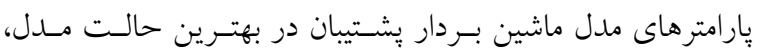

مدلها در نظر گرفت. بر اين اساس تعـداد ها ايستخاه بـهعنوان

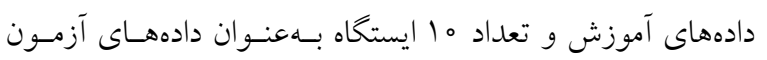
مدلها در نظر كرفته شدند. درنهايت مدلسازى دبىهاى حداكثر لحظـهاى بـا اسـتفاده از سـهـ روش ماشـين بــردار بشـتيبان، شـبكه عصـبى مصـنوعى و

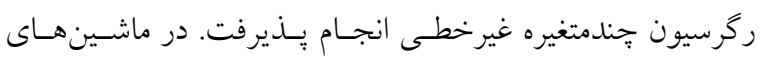
بردار يشتيبان مىبايست ابتدا مقادير بهينه يارامترهاى مورد استفاده در توابع، براى دوره بازگشتهاى مختلف مشتص شوند و يـس از ايجاد مدلها، مناسبترين تابع انتخاب شـود. بـههمـين منظـور براى انتخاب مقــادير بهينـهـ پِارامترهـا از الخـوريتم جسـتجوى دو مرحلسهاى (Two-Steps Grid Search) بـا اعتبارسـنجى متقــاطع استفاده شـــ. در ايسن روش، ابتـدا در يـك (Cross-Validation) 
نشريه علوم آب و خاك (علوم و فنون كشاورزى و منابع طبيعى) / سال بيست و سه / شماره اول / بهار \هـا

جدول ه. نتايج مدلسازى با شبكه عصبى مصنوعى در مرحله آموزش و آزمون

\begin{tabular}{|c|c|c|c|c|c|c|c|c|c|c|}
\hline NSC & $\begin{array}{l}\text { آزمون } \\
\text { RMSE }\end{array}$ & $\mathrm{R}^{r}$ & NSC & آموزش & $\mathrm{R}^{r}$ & تعراد & خروجى لايه & لايه مخفى & شبكه & دوره باز گشت \\
\hline $0 / 90$ & $19 / 94$ &.$/ 94$ & .09 & $14 / 04$ & $0 / 9 r$ & 09 & Pure line & Tanh & $r-1 r-1$ & r \\
\hline$\circ / \Delta V$ & YN/OT &.$/ 94$ &.$/ 90$ & TY/Y. & $0 / 94$ & YI & Pure line & Logistic & $k-11-1$ & 0 \\
\hline$\circ / \mathrm{VV}$ & $r V / 10$ &.$/ 9 V$ & $\circ / V V$ & $r q / 9 V$ & $\circ / \mathrm{VA}$ & 49 & Pure line & Tanh & $4-q-1$ & 10 \\
\hline$\circ / 0 \wedge$ & $4 q / 1 r$ & $\circ / \wedge \Delta$ & $0 / 94$ & Gr/Qr & $0 / 94$ & YY & Pure line & Logistic & $\varphi-\Lambda-1$ & ro \\
\hline $0 / 90$ & $O Y / Y \Lambda$ & $\circ / \wedge \Delta$ & $0 / 91$ & $\Lambda \Delta / \mu_{0}$ & $0 / 91$ & yo & Pure line & Tanh & $r-\mid r-1$ & Q. \\
\hline.$/ 01$ & $V Q / q_{0}$ & $\circ / \Lambda \circ$ & $\circ / \Delta r$ & $100 / 09$ & $\circ / D F$ & My & Pure line & Logistic & $y-t-1$ & 100 \\
\hline
\end{tabular}

جدول 9. نتايج مدلسازى با رگرسيون جندمتغيره غير خطى در مرحله آموزش و آزمون

\begin{tabular}{|c|c|c|c|c|c|c|c|}
\hline \multirow{2}{*}{ معادلات } & \multicolumn{3}{|c|}{ آزمون } & \multicolumn{3}{|c|}{ آموزش } & \multirow[t]{2}{*}{ دوره بازگشت (سال) } \\
\hline & NSC & RMSE & $\mathrm{R}^{r}$ & NSC & RMSE & $\mathrm{R}^{r}$ & \\
\hline 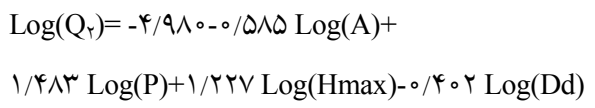 & $0 / T \wedge$ & Tr/Y。 & $0 / 91$ & $0 / 49$ & $19 / \mathrm{AV}$ & $0 / 4 T$ & r \\
\hline 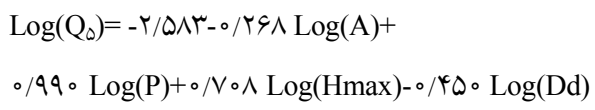 & $0 / 4 y$ & Tr/KG & . 94 & - $/ \Delta Y$ & 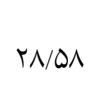 & $\circ / \Delta V$ & $\Delta$ \\
\hline $\begin{array}{l}\log \left(\mathrm{Q}_{1}\right)=-1 / Y \uparrow \vee-\circ / / \circ r \log (\mathrm{A})+ \\
\circ / V \backslash \uparrow \log (\mathrm{P})+\circ / 4 r Y \log (\mathrm{Hmax})-\circ / \uparrow \vee \circ \log (\mathrm{Dd})\end{array}$ & $\circ / 0 \circ$ & $r q / 91$ & $0 / 91$ & - & KY/G。 & $\circ / \Delta \wedge$ & 10 \\
\hline $\begin{array}{l}\log \left(\mathrm{Q}_{r \diamond}\right)=\circ / \Gamma \circ \varsigma+\circ / \circ \vee r \log (\mathrm{A})+\circ / \uparrow / \uparrow \\
\log (\mathrm{P})+\circ / \| r \log (\mathrm{Hmax})-\circ / \uparrow \wedge \Lambda \log (\mathrm{Dd})\end{array}$ & $\circ / \Delta \Delta$ & $00 / 99$ & $\circ / M$ & $\circ / \Psi V$ & VG/T & س & TQ \\
\hline $\begin{array}{l}\log \left(\mathrm{Q}_{\Delta_{0}}\right)=|/ \Gamma \Delta|+\circ / r \mu r \log (\mathrm{A})+\circ / / \Delta ৭ \\
\log (\mathrm{P})-\circ /|\uparrow| \log (\mathrm{Hmax})-\circ / \uparrow r \wedge \log (\mathrm{Dd})\end{array}$ & $0 / 01$ & 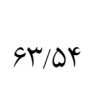 & $\circ / \Lambda \Delta$ & $\circ / 4 \circ$ & $119 / 99$ & $0 / \Psi V$ & Q. \\
\hline 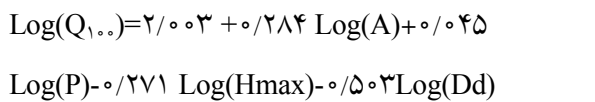 & $\circ / \mathrm{VI}$ & $\Delta N / T Y$ & $\circ / N Q$ & o/ & $\mid V T / 9 \circ$ & 。 & 100 \\
\hline
\end{tabular}

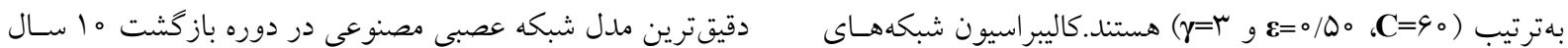

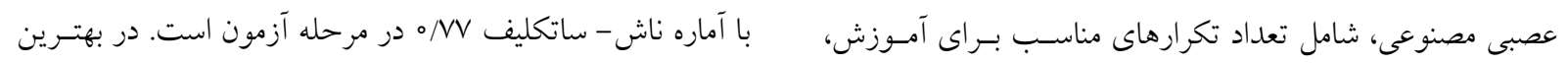

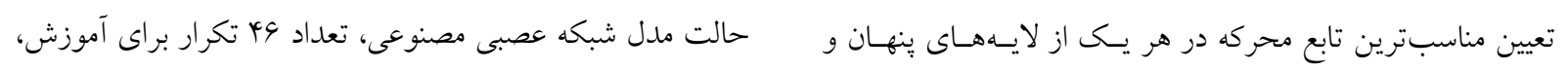

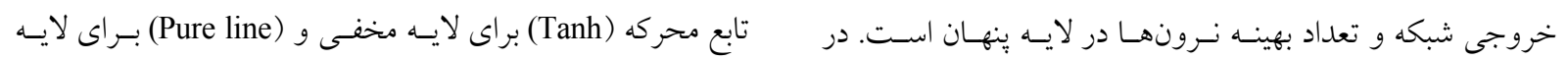

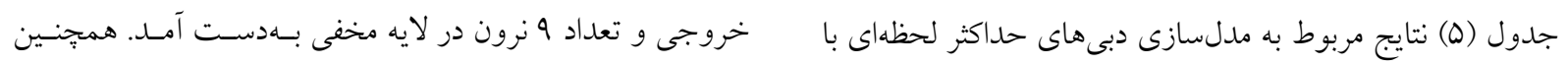

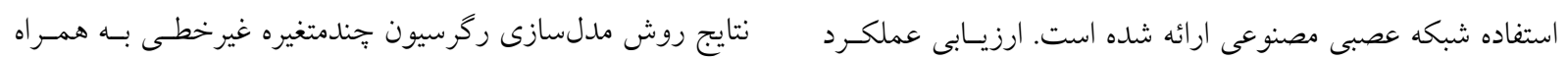

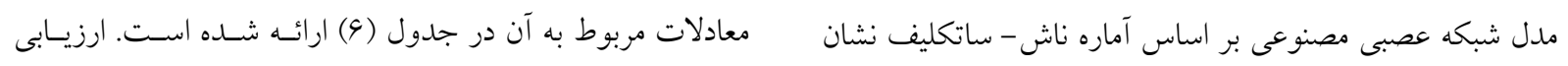

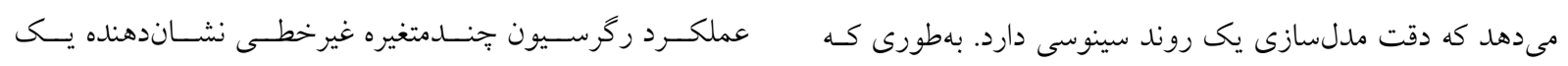




\begin{tabular}{|c|c|c|c|}
\hline MNLR & ANNs & SVM & دوره باز گشت (سال) \\
\hline ضعيف & متوسط & خيلى خوب & r \\
\hline ضعيف & متوسط & خيلى خوب & $\Delta$ \\
\hline ضعيف & خوب & خيلى خوب & 10 \\
\hline متوسط & متوسط & خيلى خوب & TQ \\
\hline متوسط & متوسط & خيلى خوب & $\omega_{0}$ \\
\hline خوب & متوسط & خوب & 100 \\
\hline
\end{tabular}

\section{نتيجه گيرى}

هدف از يزوهش حاضر مقايسه عملكرد ماشين بردار يشـتيبان بـا

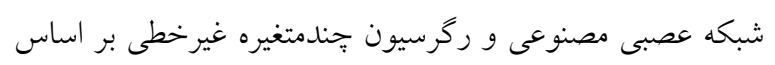
توانايى آزمون گاما در انتخاب متغيرهاى موثر بر دبىهاى حداكثر

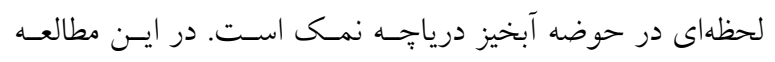

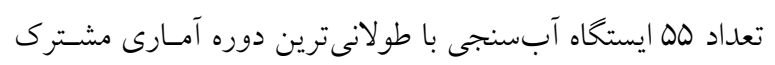

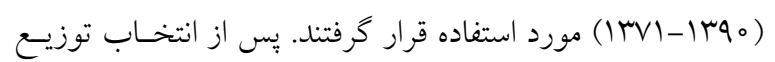

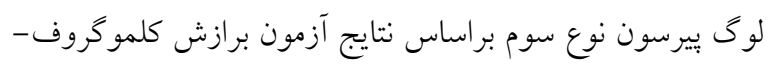

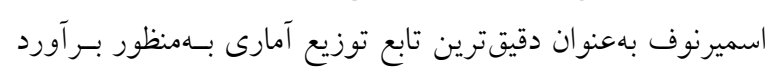
دبى هاى حداكثر لحظهاى براى دوره بازگشتهاى مختلف، نتسايج

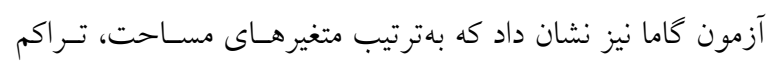
زهكشى، ارتفاع حداكثر و محيط بهعنوان متغيرهاى مؤثر بـر دبسى

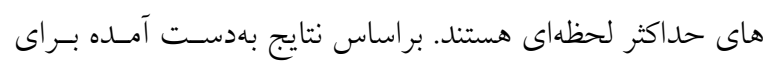
هركدام از روشهاى مدلسازى ملاحظه مىشود كـه دقيـقترين

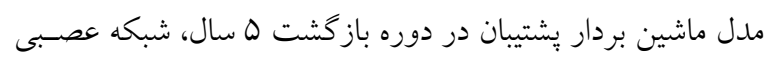
مصسنوعى در دوره باز گشـت ه ما سـال و رگرسـيون جنــدمتغيره

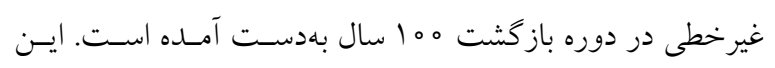
نتايج نشان مىدهد كه دقيقترين مدلهاى ماشين بردار يشـيبان و شبكه عصبى مصنوعى در دوره باز گشت كوتاهمدت و دقيقتسرين

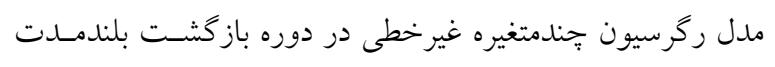
بهدست آمده است. درنهايت يس از بررسى كمى و كيفى هركـدام

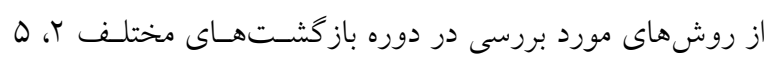

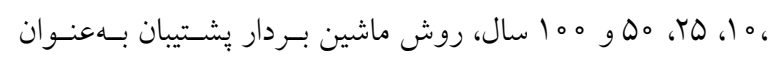

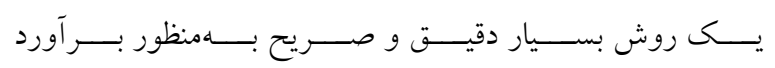

روند افزايشى در دقت مدلسازى تا دوره باز گثـت فT سـال بـر اساس آماره ناش - ساتكليف است. يس از يك روند كاهشسى در

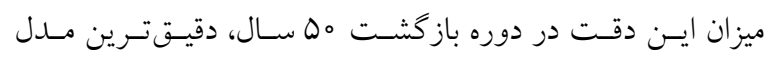
ركرسيون جندمتغيره غيرخطى در دوره باز گثـت ه م إنسال بـا

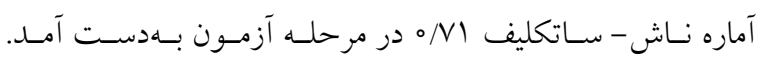
درنهايت مقايسه جداول (Y) تا (Y) نشان مىدهد كه روش ماشين بردار بشتيبان از دقت بهمراتب بيشترى نسبت به دو روش شـبكه

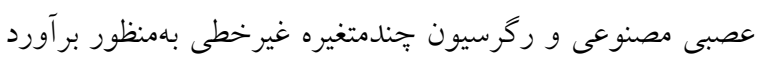

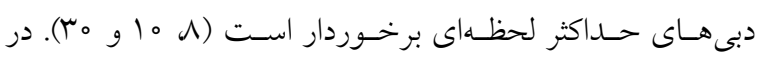
استفاده از روش ماشين بردار يشتيبان، از بـين توابـع كرنـل، تـابع كرنل RBF در تمام دوره باز گشتهاى مورد نظر بهترين نتسايج را نشان داد (ه، \& أو سY). همجينين بهمنظور مقايسه كيفى مدلهـاى

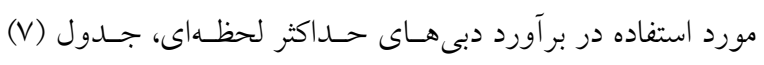
شده است. براى اين منظور با استفاده از آماره نـاش - سـاتكليف،

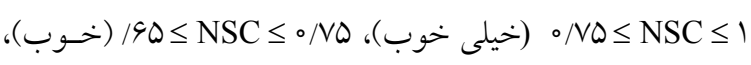

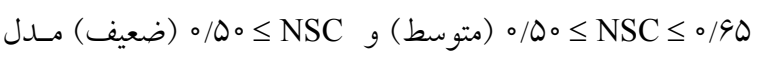
ها در جهار گروه طبقهبندى مىشوند (11). مقايسـه كيفى روش هاى مورد استفاده نيز نشان داد كه اكثر مــلهــاى ماشـين بــردار يشتيبان در طبقه (خيلى خوب) و مدلهاى شبكه عصبى مصنوعى در طبقه (متوسط) قرار مى گيرند. از طرفى ديخر نتايج اين بررسى نشان داد كه بيشتر مدلهـاى رگرسـيون جنــدمتغيره غيرخطى در

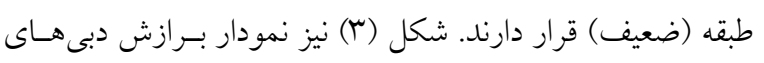

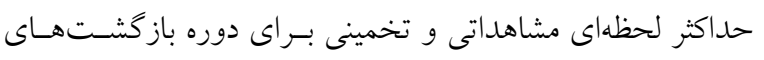
مختلف در مرحله آزمون را نشان مىدهد. 
نشريه علوم آب و خاك (علوم و فنون كشاورزى و منابع طبيعى) / سال بيست و سه / شماره اول / بهار \هـا
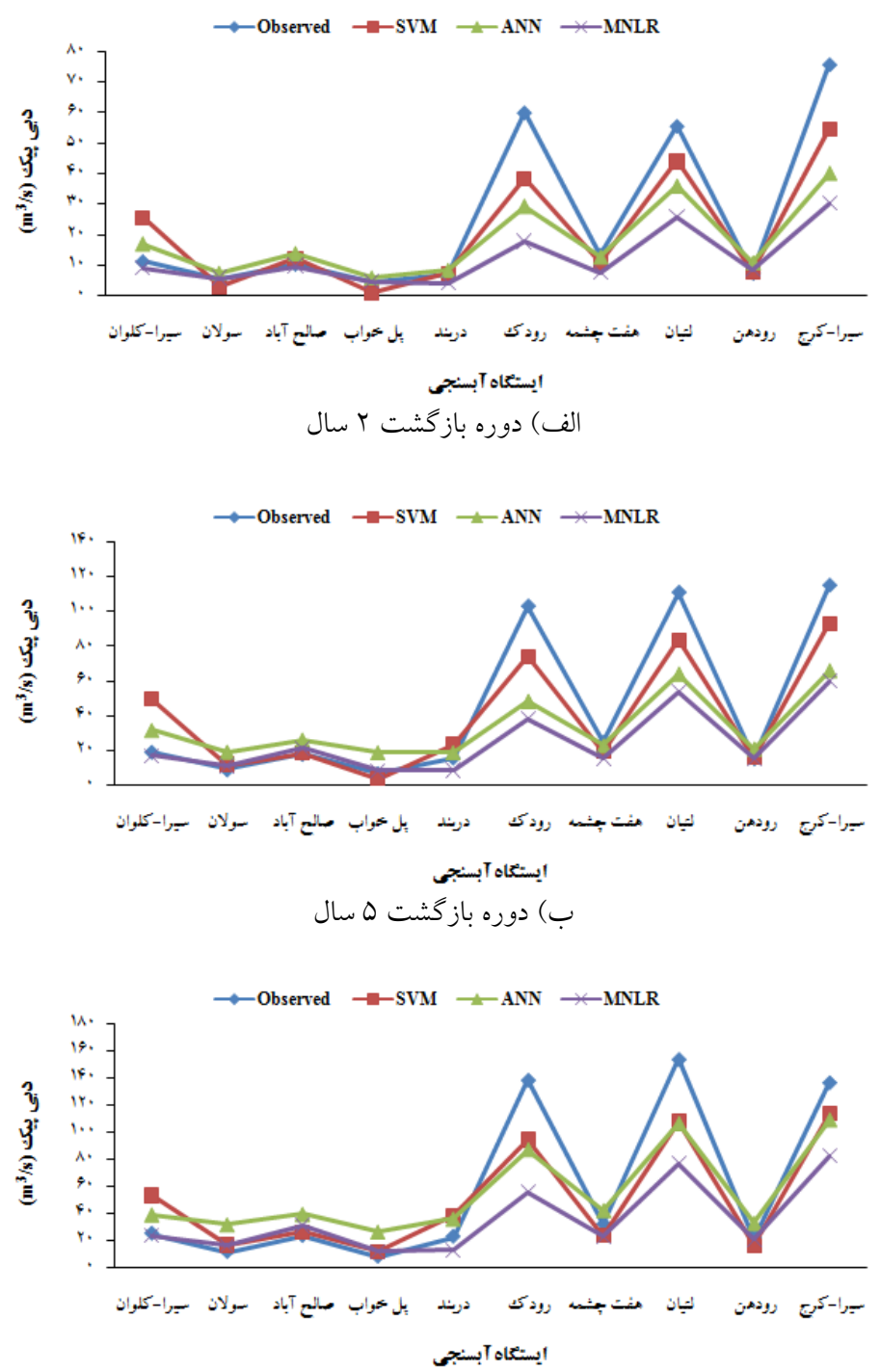

ج) دوره باز گشت ابنش م1 سال

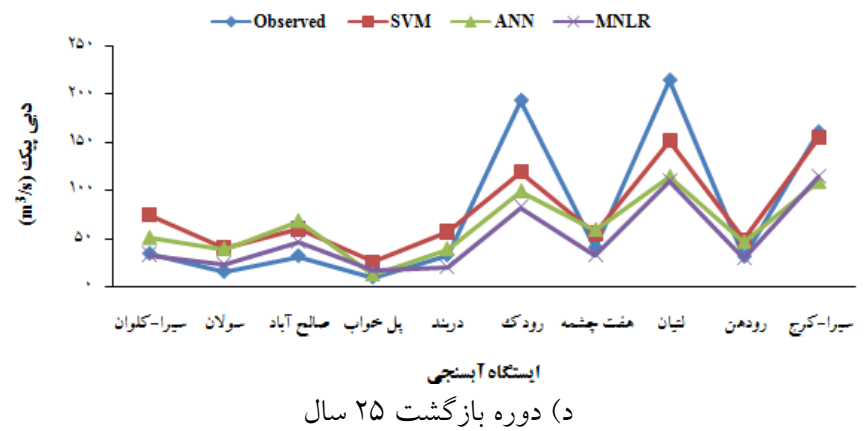

شكل r. نمودار برازش دادههاى مشاهداتى و تخمينى در دوره باز گشتهاى مختلف 

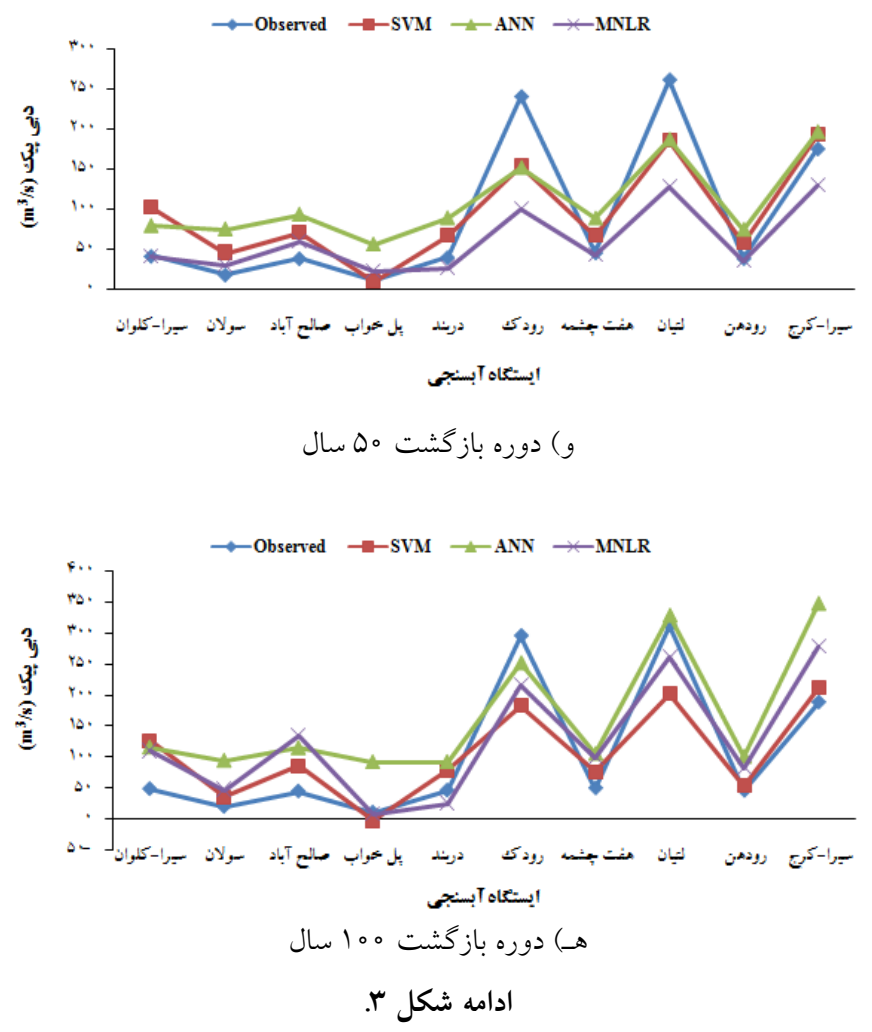

$$
\begin{aligned}
& \text { دبىهاى حداكثر لحظهاى در حوضه آبخيز درياجٍه نمك نسبت به روشهاى مدلسازى ماشين بردار يشتيبان، شبكه عصبى مصنوعى } \\
& \text { دو روش شبكه عصبى مصنوعى و رگرسيون جنامتغيره غيرخطى و رگرسيون جنامتغيره غيرخطى بهترتيب بهعنـوان مناسـبـــرين } \\
& \text { معرفى شد. همجنين اين مقايسه دقـت مــلهــاى شـبكه عصـبى روش مدلسازى دادههاى دبى حداكثر لحظهاى در حوضه آبخيـز }
\end{aligned}
$$

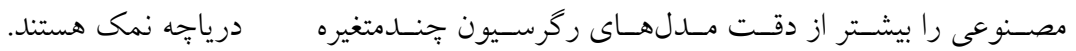

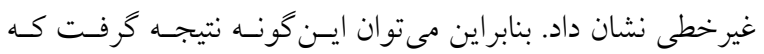

\section{منابع مورد استفاده}

1. Ahn, J., W. Cho, T. Kim, H. Shin and J-H. Heo. 2014. Flood frequency analysis for the annual peak flows simulated by an event-based rainfall-runoff model in an urban drainage basin. Water 6(12): 3841-3863.

2. Alizadeh, A. 2006. Principles of Applied Hydrology (18 $8^{\text {th }}$ Ed). The Imam Reza University Press. Iran. (In Farsi).

3. Aziz, K., A. Rahman, G. Fang and S. Shrestha. 2013. Application of artificial neural networks in regional flood frequency analysis: a case study for Australia. Stochastic Environmental Research and Risk Assessment 28(3): 541554.

4. Bloscle, G. and M. Sivapalan. 1997. Process controls on regional flood frequency: coefficient of variation and basin scale. Water Resources Research 33(12): 2967-2980.

5. Daliri, M., M. Javadi and S. Abedkouhi. 2014. Traffic signs detection and recognition by using a method based on attention mechanism and classical and support vector machine classifier. Journal of Transportation Engineering 4(4): 333-344 (In Farsi).

6. Dawson, C. W., R. J. Abrahart, A. Y. Shamseldin and R. L. Wilby. 2006. Flood estimation at ungauged sites using artificial neural networks. Journal of Hydrology 319(1-4): 391-409.

7. Dogan, E., M. Gumrukcuoglu, M. Sandalci and M. Opan. 2010. Modelling of evaporation from the reservoir of 
Yuvacik dam using adaptive neuro-fuzzy inference systems. Engineering Applications of Artificial Intelligence 23(6): 961-967.

8. Esen, H., M. Inalli, A. Sengur and M. Esen. 2008. Modeling a ground-coupled heat pump system by a support vector machine. Renewable Energy 33(8): 1814-1823.

9. Eslami, A. R. and B. Saghafian. 2008. The role of watershed morphometric and climatic factors in producing of flood flows. Pajouhesh and Sazandegi 78: 149-157 (In Farsi).

10. Eslamian, S. S., J. Abedi-Koupai, M. J. Amiri and S. A. Gohari. 2009. Estimation of daily reference evapotranspiration using support vector machines and artificial neural networks in greenhouse. Environmental Sciences 4: 439-447.

11. Fatehi, I., B. J. Amiri, A. Alizadeh and J. Adamowski. 2015. Modeling the relationship between catchment attributes and in-stream water quality. Water Resources Management 29(14): 5055-5072.

12. Ghabaei Sough, M., A. Mosaedi, M. Hesam and A. Hezarjaribi. 2010. Evaluation effect of input parameters preprocessing in artificial neural networks (ANNs) by using stepwise regression and gamma test techniques for fast estimation of daily evapotranspiration. Journal of Water and Soil 24(3): 610-624 (In Farsi).

13. Gizaw, M. S. and T. Y. Gan. 2016. Regional flood frequency analysis using support vector regression under historical and future climate. Journal of Hydrology 538: 387-398.

14. Goel, A. and M. Pal. 2012. Stage-discharge modeling using support vector machines. Internatinal Journal of Engineering 25(1): 1-9.

15. Hall, M. G. and A. V. Minns. 1998. Regional flood frequency analysis using artificial neural networks. Journal of Hydroinformatics 98(2): 759-763.

16. Jaydari, A., A. Fathzadeh, R. Taghizadeh Mehrjardi, M. T. Dastorani and A. Fatahi Ardakani. 2012. Comparison of the efficiency of different methods for reconstruction and prolongation of instantaneous peak flow data. Journal of Range and Watershed Management (Iranian Journal of Natural Resources) 64(4): 387-399. (In Farsi).

17. Jones, A. J. 2004. New tools in non-linear modeling and prediction. Computational Management Science DOI: 10.1007/s10287-003-0006-1. 109-149.

18. Karim, M. A. and J. U. Chowdhury. 1995. A comparison of four distributions used in flood frequency analysis in Bangladesh. Hydrological Sciences Journal 40(1): 55-66.

19. Khosravi, M., A. Salajegheh, M. Mahdavi and M. Mohseni Saravi. 2012. Flood forecasting using artificial neural networks and nonlinear multivariate regression (Case Study: Taleghan Watershed). Journal of Range and Watershed Management (Iranian Journal of Natural Resources) 65(3): 341-349 (In Farsi).

20. Kia, M. 2018. Soft Computing using MATALAB (5 $5^{\text {th }}$ Ed). Kian Publication. Iran. (In Farsi).

21. Kurtulus, B. and M. Razack. 2010. Modeling daily discharge responses of a large karstic aquifer using soft computing methods: artificial neural network and neuro-fuzzy. Journal of Hydrology 381(1): 101-111.

22. Menhaj, M. 2005. Basis of Artificial Neural Network (Calculative Intelligence). Publication Center of Poly Technic University Press. Tehran. Iran. (In Farsi).

23. Minns, A. W. and M. J. Hall. 1996. Artificial neural network as rainfall-runoffmodel. Hydrological Sciences Journal 41(3): 399-417.

24. Moghadamnia, A., M. Ghafari, J. Piri and D. Han. 2008. Evaporation estimation using support vector machines technique. Engineering and Technology 33: 14-22.

25. Moghimi, A., S. R. Moussavi, A. Motamed and H. Ahmadi. 2010. Study of morphometry factors regressions of chalus drainage basin using statistical methods and mathematical models. Journal of Earth and Resources 2(1): 6580 (In Farsi).

26. Nabizadeh, M., A. Mosaedi, M. Hesam and A. A Dehghani and M. Meftah. 2012. River flow forecasting using fuzzy inference system (FIS) and adaptive neuro-fuzzy inference system (ANFIS). Iranian Journal of Watershed Management Sinence and Engineering 17(5): 7-14 (In Farsi).

27. Nabizadeh, M., A. Mosaedi, M. Hesam and A. A Dehghani. 2012. Comparing the performance of fuzzy based models in stream flow forecasting on Lighvan River. Journal of Water and Soil Conservation 19(1): 117-134 (In Farsi).

28. Najmaii, M. 1991. Engineering Hydrology. ( $2^{\text {th }}$ Ed). Science and Technology University Press. Iran. (In Farsi).

29. Noori, R., A. R. Karbassi, A. Moghaddamnia, D. Han, M. H. Zokaei-Ashtiani, A. Farokhnia and M. Ghafari Gousheh. 2011. Assessment of input variables determination on the SVM model performance using PCA, Gamma test and forward selection techniques for monthly stream flow prediction. Journal of Hydrology 401(3-4): 177-189.

30. Radhika, Y. and M. Shashi. 2009. Atmospheric temperature prediction using support vector machines. International Journal of Computer Theory and Engineering 1(1): 1793-8201.

31. Rezai, A., M. Mahdavi, K. Lox, S. Feyznaya and M. H. Mehdian. 2007. Regional peak flows modelling of Sefidrood dam's sub basins using artificial neural network. Journal of Science and Technology of Agriculture and Natural Resources 11: 25-39 (In Farsi). 
32. Seckin, N. and A. Guven. 2012. Estimation of peak flood discharges at ungauged sites across Turkey. Water Resource Management 26: 2569-2581.

33. Seefi, A., M. Mirlatifi and H. Reahi. 2013. Introduction and application of least square support vector machine (LSSVM) for simlulation of reference evapotranspiration and uncertainty analysis of results (A Case Study of the Kerman City). Irrigation and Water Engineering 13(4): 67-79 (In Farsi).

34. Sharifi, A. R., Y. Dinpashoh, A. Fakheri-Fard and A. R. Moghaddamnia. 2014. Optimum combination of variables for runoff simulation in Amameh watershed using gamma test. Water and Soil Science 23(4): 59-72 (In Farsi).

35. Shu, C. and T. B. M. J. Ouarda. 2008. Regional flood frequency analysis at ungauged sites using the adaptive neurofuzzy inference system. Journal of Hydrology 349: 31- 43.

36. Topaloulu, F. 2002. Determining suitable probability distribution models for flow and precipitation series of the Seyhan river basin. Turkish Journal of Agriculture and Forestry 26: 187-194.

37. Vafakhah, M. 1999. Estimated regional frequency of low-flow in the season rivers (Case Study the Arid Regione of Central Iran). MSc. Thesis, Tarbiat Modares University. (In Farsi).

38. Vapnik, V. 1995. The Nature of Statistical Learning Theory. Springer. New York.

39. Vasant, S. A. and S. D. Talegaokar. 2014. Hydrological study of man (Chandrabhaga) river. International Journal of Advances in Engineering and Technology 3(7): 807-817.

40. Viola, F., V. Noto, M. Cannarozzo and G. La Loggia. 2011. Regional flow duration curves for ungauged sites in Sicily. Hydrology Earth System Science 15: 323-331.

41. Zakaria, A. Z. and A. Shabri. 2012. Streamow forecasting at ungagged sites using support vector machines. Applied Mathematical Sciences 60(6): 3003-3014. 


\title{
Assessment the Performance of Support Vector Machine and Artificial Neural Network Systems for Regional Flood Frequency Analysis (A Case Study: Namak Lake Watershed)
}

\author{
E. Shrifi Garmdareh ${ }^{1}$, M. Vafakhah ${ }^{1 *}$ and S. Eslamian ${ }^{2}$
}

(Received: May 23-2015 ; Accepted: June 9-2018)

\begin{abstract}
Flood discharge estimation with different return periods is one of important factors for water structures design and installation. On the other hand, a lot of rivers existing in Iran watersheds have no complete and accurate hydrometric data. In these cases, one of the suitable solutions to estimate peak discharges with different return periods is the regional flood analysis. In this research, 55 hydrometric stations were used. For this purpose, at first, peak discharges in different return periods were estimated using the EasyFit software. Then, the effective variables on the peak discharges were collected and the input variables of the models were selected by using gamma test with the help of the WinGamma software. Finally, data modeling was performed using the support vector machine, artificial neural networks and nonlinear multivariate regression techniques. Quantitative and qualitative assessment of the results using various indices including Nash-Sutcliffe Efficiency Coefficient (NSC) showed that SVM modeling method had the most accuracy in comparison to the other two modeling methods to predict the peak discharges in the Namak Lake Watershed.
\end{abstract}

Keywords: Hydrometric Stations, Return Period, Gamma Test, Support Vector Machine, Namak Lake Watershed

1. Department of Watershed Management Engineering, Faculty of Natural Resources, Tarbiat Modares University, Nour, Iran.

2. Department of Water Engineering, College of Agriculture Engineering, Isfahan University of Technology, Isfahan, Iran.

*: Corresponding Author, Email: vafakhah@modares.ac.ir 